\title{
Longitudinal Seismic Behavior of a Single-Tower Cable-Stayed Bridge Subjected to Near-Field Earthquakes
}

\author{
J. Yi and J. Li \\ Department of Bridge Engineering, Tongji University, Shanghai, China \\ Correspondence should be addressed to J. Li; lijianzh@tongji.edu.cn
}

Received 21 December 2016; Accepted 20 February 2017; Published 13 March 2017

Academic Editor: Paulo B. Gonçalves

Copyright ( 2017 J. Yi and J. Li. This is an open access article distributed under the Creative Commons Attribution License, which permits unrestricted use, distribution, and reproduction in any medium, provided the original work is properly cited.

\begin{abstract}
Cable-stayed bridges are quite sensitive to large amplitude oscillations from earthquakes and seismic damage was observed for Shipshaw Bridge and Chi-Lu Bridge during past earthquakes. In order to investigate seismic damage of cable-stayed bridges, a $1: 20$ scale model of a single-tower cable-stayed bridge with A-shaped tower was designed, constructed, and tested on shake tables at Tongji University, China. One typical near-field ground motion was used to excite the model from low to high intensity. Test result showed that severe structural damage occurred at the tower of the model including parallel concrete cracks from bottom to nearly half height of the tower, concrete spalling, and exposed bars at top tower $0.2 \mathrm{~m}$ above the section where two skewed legs intersect. Posttest analysis was conducted and compared with test results. It is revealed that the numerical model was able to simulate the seismic damage of the test model by modeling nonlinearity of different components for cable-stayed bridges, namely, the tower, bents, superstructure, cables, and bearings. Numerical analysis also revealed that cable relaxation, which was detected during the test, had limited influence on the overall seismic response of the bridge with maximum error of $12 \%$.
\end{abstract}

\section{Introduction}

In recent decades, cable-stayed bridges have become popular worldwide due to their aesthetical appearance, structural efficiency, and short construction period. This type of structure, usually representing key points of the transportation networks, is normally required to remain nearly elastic under the design seismic action, as recommended in Chinese Code [1]. However, due to low structural damping, cable-stayed bridges are quite sensitive to large amplitude oscillations from earthquakes and nonlinear seismic response is anticipated. For example, during Great East Japan Earthquake (2011), the Yokohama Bay Bridge went through much nonlinearity of the response as evidenced by variations in natural frequencies and mode shapes [2]. Even worse, some structural damage was observed during past earthquakes. The first reported seismic damage of cable-stayed bridges is Shipshaw cable-stayed bridge in 1988 Saguenay Earthquake [3, 4]. An anchorage plate underneath the deck failed due to stress increments during earthquake and the abutment concrete was damaged from pounding of deck against the abutment. During 1999 Chi-Chi Earthquake, much more severe damage was observed at Chi-Lu cable-stayed bridge $[5,6]$. The damage included (1) bending failure of the superstructure at the superstructure pylon connection, (2) bending failure of the pylon above the pile cap and above the superstructure to pylon connection with concrete spalling, (3) pounding damage at the end span supports, and (4) anchorage failure of a cable stay.

Upon the nonlinear response and structural damage observed during earthquakes, some cable-stayed bridges have permitted controllable damage at tower legs under extreme seismic event, like Rion-Antirion bridge in Greece [7] and Stonecutters in Hong Kong, China [8]. In Japanese code [9], the main tower of cable-stayed bridge is allowed with plastic behavior by carefully investigating and designing its plastic ranges. Meanwhile, several studies have been conducted in an attempt to reveal elastic-plastic seismic response of cablestayed bridges. Camara and Astiz [10] proposed coupled pushover analysis to estimate the complex inelastic response of cable-stayed bridges and revealed the contribution of higher modes (approximately between $1 \mathrm{~Hz}$ and $25 \mathrm{~Hz}$ ) is significant in seismic response. $\mathrm{Li}$ et al. [11] conducted damage analysis of a three-tower cable-stayed bridge with 


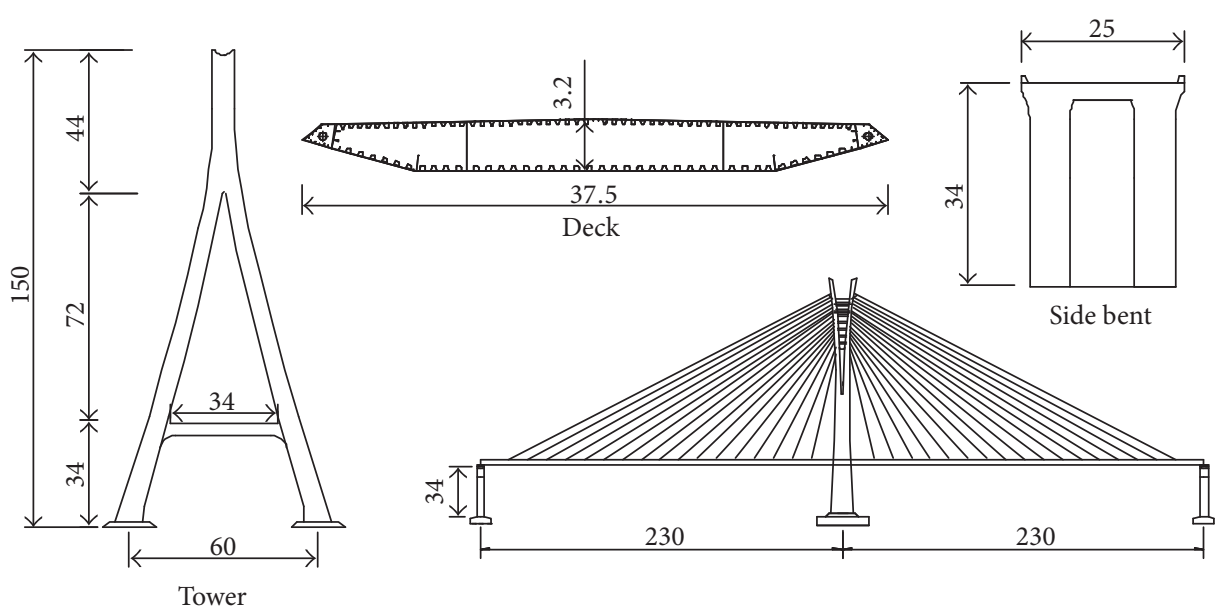

Figure 1: Schematic of the Puqian cable-stayed Bridge [m].

rigid system, floating system, and passive energy dissipation system, revealing that plastic hinge may form at either the bottom of middle tower or side tower, depending on different systems. However, as highlighted by the damage of Chi-Lu Bridge $[5,6]$, all composing parts of cable-stayed bridges, namely, the tower, deck, cables, and bearings, might go through nonlinear stage while current studies mainly focused on one or two parts of the cable-stayed bridges.

On the other hand, near-field ground motions exert a large influence on cable-stayed bridges which have a number of long-period modes [12]. In recent decades, several nearfield ground motions have been recorded during past earthquakes as Parkfield (1966), San Fernando (1971), Kobe (1995), Chi-Chi (1999), and South Napa (2014) [13] events. Comparing to typical far-field ground motions, near-filed ground motions usually contained long-duration pulses and high peak ground velocities [14]. Cable-stayed bridges are quite sensitive to near-field ground motions since large amplitude spectral acceleration of near-field ground motions usually occurred at long periods where many cable-stayed bridges have significant structural response modes. For instance, it was speculated that damage of Chi-Lu bridges was likely caused by ground motion pulses from the near-field ground motion at the bridge site [6].

To recognize all nonlinear response of cable-stayed bridges subjected to near-field ground motions, one of the most obvious and effective ways is through shake table tests. Shake table tests can excite structures in such a way that they are subjected to conditions representing true earthquake ground motions and verify the analysis results from different numerical methods, as the case of Jindo Bridge [15] and Taizhou Changjiang Bridge [16]. Several shake table tests have been conducted regarding structural damage of cable-stayed bridges under earthquakes. Duan [17] firstly conducted a $1 / 20$ scale tower model of a cable-stayed bridge. Test results showed that (1) several cracks appeared and extended at the bottom of tower legs and at the middle of tower legs near the lower strut and (2) the bottom of the tower was seriously damaged with concrete spalling and steel bars fractured and exposed approximately $30 \mathrm{~cm}$ of the plastic region. But with lack of corresponding cable and deck systems in the model, the applicability of the test results needed to be further verified. So a $1 / 20$ scale full cable-stayed bridge model was designed and tested on shake tables by Wang et al. [18]. By exciting the model transversely, the test result showed the damage characteristics of a cable-stayed bridge with $\mathrm{H}$ shaped tower in transverse direction including: (1) severe damage at the upper strut with several steel bars fractured at both ends, (2) repairable damage at the bottom and middle part of tower legs with concrete cover spalling and exposure of steel bars, and (3) minimal damage at the lower strut with slight concrete spalling.

This paper introduced another 1:20 full-scale model of a single-tower cable-stayed bridge which was excited longitudinally on shake tables at Tongji University, China. The design details of test model were described and the validation of the test model was conducted. One typical nearfield ground motion was used to excite the model from low to high intensity and the observed damage and test results were presented. Posttest model was conducted and analyses results were compared with test results so as to check the adequacy of existing nonlinear analytical techniques in estimating seismic response of cable-stayed bridges under near-field ground motions. The influence of cable relaxation which was detected during the test was also studied. The objective of this test is to study structural damage of cable-stayed bridges under longitudinally excited earthquakes.

\section{Bridge Model}

2.1. Prototype Bridge. The prototype bridge, Puqian Bridge, spans Puqian sea area which lies in the northeast of Hainan province, China. It is a symmetric single-tower cable-stayed bridge with two 230 spans, as is shown in Figure 1. The concrete A-shape tower is $150 \mathrm{~m}$ high from bottom to tower top and $60 \mathrm{~m}$ wide at the foundation level. The rectangular crossbeam of the tower is at elevation $34 \mathrm{~m}$ and two skewed legs intersect at elevation $106 \mathrm{~m}$. The deck is composed by a closed steel box, which is $37.5 \mathrm{~m}$ wide and $3.2 \mathrm{~m}$ high at 
TABLE 1: Material properties of Puqian Bridge.

\begin{tabular}{lcccc}
\hline Structural components & Material & Elastic modulus $(\mathrm{GPa})$ & Yield stress $(\mathrm{MPa})$ & $\mathrm{Density}\left(\mathrm{kg} / \mathrm{m}^{3}\right)$ \\
\hline \multirow{2}{*}{ Tower and bents } & Concrete & 34.5 & 32.5 & 2600 \\
& Steel bar & 210 & 400 & 7850 \\
Deck & Steel plate & 210 & 345 & 7850 \\
Cables & Steel strand & 195 & 1860 & 7850 \\
\hline
\end{tabular}

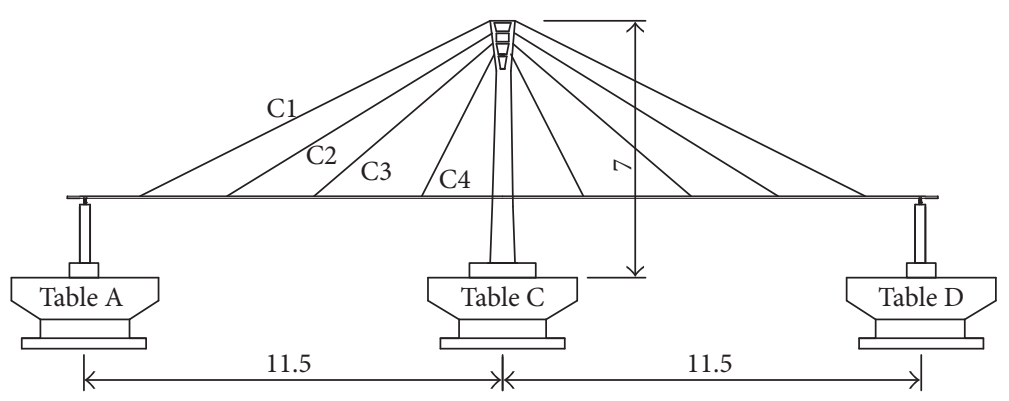

FIGURE 2: Bridge model and arrangement of shake tables [m].

TABLE 2: Self-weight and additional masses of the model.

\begin{tabular}{lccc}
\hline Components & $\begin{array}{c}\text { Self-weight } \\
(\mathrm{kg})\end{array}$ & $\begin{array}{c}\text { Additional } \\
\text { mass }(\mathrm{kg})\end{array}$ & $\begin{array}{c}\text { Total mass } \\
(\mathrm{kg})\end{array}$ \\
\hline Tower & 3336 & 15200 & 18536 \\
Deck & 2453 & 6216 & 8669 \\
Bents & 1440 & 4200 & 5640 \\
Cables & 26 & - & 26 \\
\hline
\end{tabular}

middle span. The stay cable arrangement is a two-verticalplane system and totally 68 cable strands are used to support the deck. The concrete side bent is a portal frame which is $34 \mathrm{~m}$ high and $25 \mathrm{~m}$ wide. The deck of the bridge was vertically supported on bents and towers through spherical steel bearings which can slide longitudinally, while transversely being fixed to the side bents and towers by shear keys. Table 1 lists the material properties of prototype bridge.

\subsection{Test Model}

2.2.1. Scale Factors. According to the available testing system and the prototype of the bridge, the shake table bridge model is designed as a 1:20 scale geometric model of prototype. With this scale, the total height of the model from the base of the footing to the tower top was $7 \mathrm{~m}$, and the total length was $23 \mathrm{~m}$. Three shake tables, Tables A, C, and D, were used to support the test model, as shown in Figure 2. The payloads of Tables A and D are $30 \mathrm{t}$ and those of Tables C are $70 \mathrm{t}$. All the tables have the dimension of $6 * 4 \mathrm{~m}$ and maximum acceleration of $1.0 \mathrm{~g}$.

In order to simulate the gravity effect, the acceleration scale factor was set to 1 . Therefore, additional mass is added to increase the density of the structure and to produce a realistic dead load and inertial force. Table 2 lists the self-weight and the additional mass attached to the model. In total, the test
TABLE 3: Test results of microconcrete specimens.

\begin{tabular}{lcccc}
\hline Elastic modulus & Specimen 1 & Specimen 2 & Specimen 3 & Average \\
$(\mathrm{GPa})$ & 12.80 & 10.59 & 11.25 & 11.6 \\
\hline Compressive & Specimen 1 & Specimen 2 & Specimen 3 & Average \\
stress (MPa) & 13.3 & 13.8 & 13.2 & 13.4 \\
\hline
\end{tabular}

model has a weight of $32871 \mathrm{~kg}$, including $7255 \mathrm{~kg}$ self-weight and $25616 \mathrm{~kg}$ additional mass.

2.2.2. Tower and Bents Design. Buckingham $\pi$ theorem of dimensional analysis [19] was performed to design the model. Basically, the bridge model should provide a realistic representation of the prototype bridge response. However, if strictly following geometric scaling factor of $1 / 20$, the minimum thickness of tower plate would be $40 \mathrm{~mm}$, making it too difficult to manufacture the model. To solve the construction problem, the thickness of the tower and bents was enlarged to $80 \mathrm{~mm}$ while strictly following the scaling factor of flexural stiffness. Meanwhile, in order to reduce the total weight of the model [15], microconcrete was used to substitute the prototype concrete and its elastic modulus was designed to be $1 / 3$ of the prototype material. Available rebar with the minimum diameter of $6 \mathrm{~mm}$ in Chinese commercial market was used to substitute $36 \mathrm{~mm}$ rebar of the prototype. The number and arrangement of rebars were properly designed so that the towers and bent columns of the test model would have the same shear and bending capacity exactly scaling down from the prototype bridge. Details of designed tower and bents are shown in Figure 3.

Before shake table tests, material tests for microconcrete were conducted through static modulus of elasticity in compression. Table 3 lists the test results of microconcrete specimens. The testing elastic modulus was $11.6 \mathrm{GPa}$, almost equal to $1 / 3$ of elastic modulus of the prototype material 


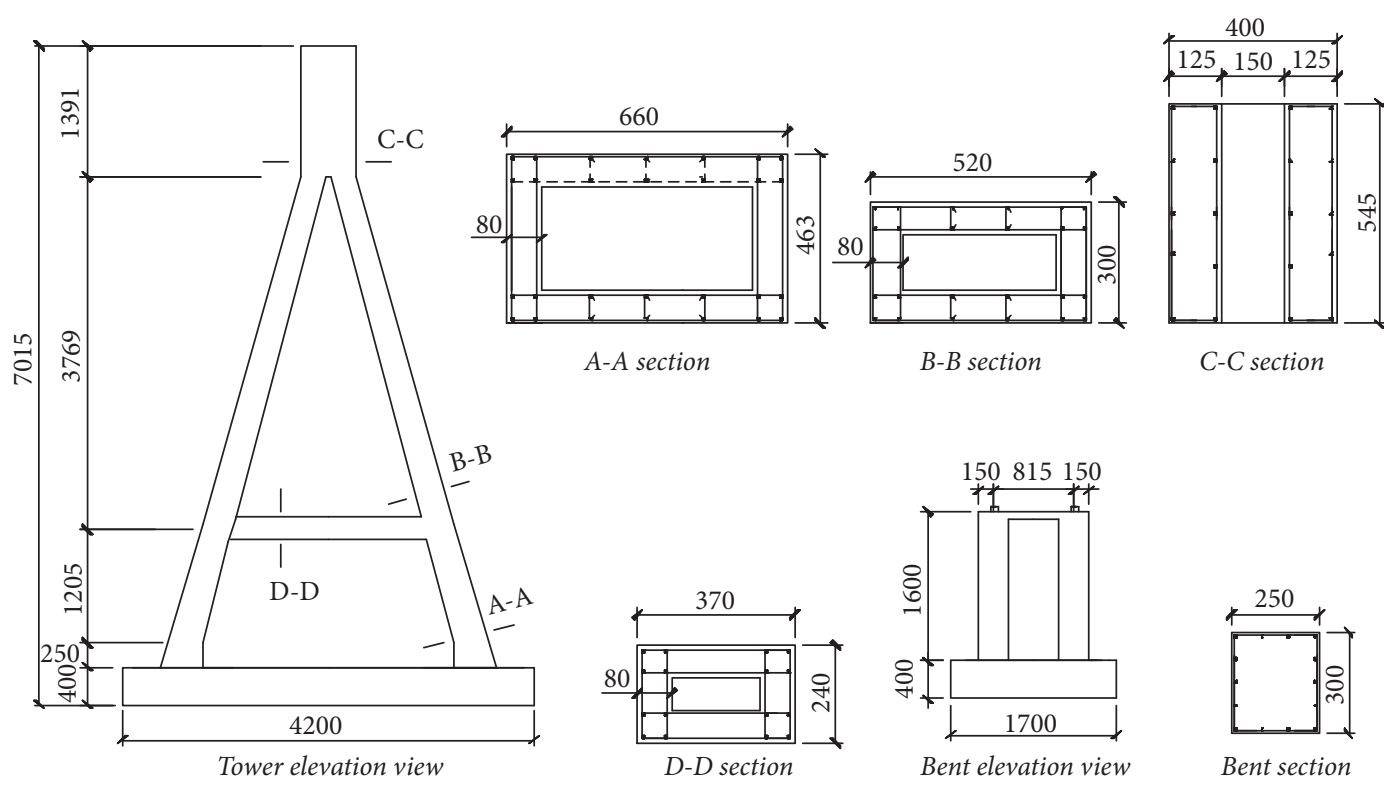

FIGURE 3: Details of the tower and bents design [mm].

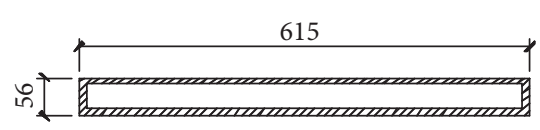

Deck section

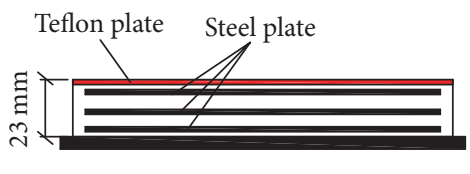

Teflon sliding bearing

Figure 4: Details of the deck and sliding bearing design [mm].

as designed, and the average compressive strength of the microconcrete was $13.4 \mathrm{MPa}$.

2.2.3. Deck and Cable Design. To simplify construction, a regular box section composed of $10 \mathrm{~mm}$ thick steel plate was designed to substitute the streamlined, flat, thin-walled steel box, as shown in Figure 4. The model steel box had the exact scaling bending moment of inertia about both strong and weak axes from the prototype box. Six Teflon sliding bearings, as also shown in Figure 4, were distributed to the tower and bents to support the deck.

High-strength stainless steel wires were used for cables of test model. In order to simplify the construction, 68 cables from the prototype bridge were condensed to 16 cables for the test model. According to the principles of equivalent cable forces and dynamic characteristics from the prototype, each cable had a cross-sectional area of $7.85 \times 10^{-5} \mathrm{~mm}^{2}$.

2.2.4. Assembled Bridge Model. The assembled bridge model is shown in Figure 5. Out of safety consideration, a gatestyle frame was used above each transition pier to restrain vertical movement at deck end so that end span uplift effect is prevented [5].

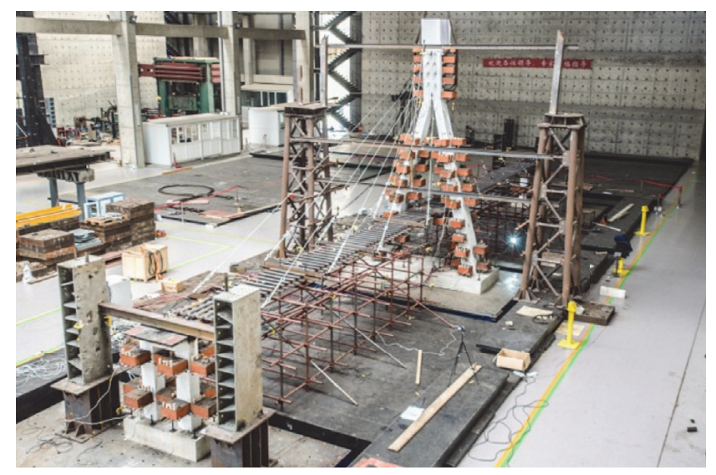

Figure 5: Assembled bridge model.

\section{Testing Protocol}

In order to study the near-fault effects on the seismic damage of cable-stayed bridges, one typical near-fault ground motion, TCU052 from the 1999 Chi-Chi Earthquake [20], was used to excite the test model. To account for the scale effect of the test model, the time axis of the prototype motion was compressed by $0.2236(1 / \sqrt{20})$. Figure 6 shows the input records with a compressed time axis and scaled amplitude 
TABLE 4: Comparison of target and achieved peak ground acceleration.

\begin{tabular}{lccc}
\hline Cases & Target PGA $(\mathrm{g})$ & Achieved PGA $(\mathrm{g})$ & Ratios \\
\hline Case 1 & 0.05 & 0.051 & 1.02 \\
Case 2 & 0.1 & 0.103 & 1.03 \\
Case 3 & 0.15 & 0.164 & 1.09 \\
Case 4 & 0.2 & 0.212 & 1.06 \\
Case 5 & 0.25 & 0.265 & 1.06 \\
Case 6 & 0.3 & 0.31 & 1.03 \\
Case 7 & 0.35 & 0.364 & 1.04 \\
Case 8 & 0.4 & 0.418 & 1.05 \\
Case 9 & 0.45 & 0.464 & 1.03 \\
Case 10 & 0.5 & 0.506 & 1.01 \\
Case 11 & 0.55 & 0.547 & 0.99 \\
Case 12 & 0.6 & 0.594 & 0.99 \\
Case 13 & 0.65 & 0.648 & 1.00 \\
Case 14 & 0.7 & 0.728 & 1.04 \\
Case 15 & 0.75 & 0.78 & 1.04 \\
Case 16 & 0.8 & 0.812 & 1.02 \\
\hline
\end{tabular}

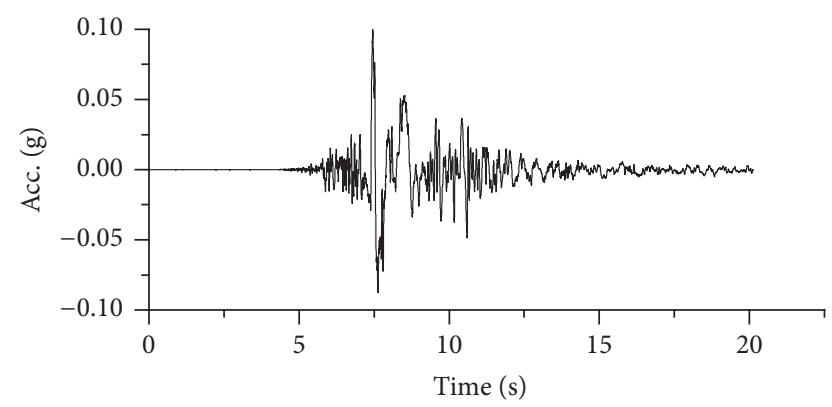

FIGURE 6: Input motions with compressed time axis and scaled amplitude.

$($ PGA $=0.1 \mathrm{~g})$. During the test, the TCU052 waves were applied with the increasing PGA from 0.05 to $0.80 \mathrm{~g}$ in the longitudinal direction. In order to determine changes in structural period so as to evaluate the stiffness degradation of the model, white noise excitation was applied at the beginning of the test and between each earthquake test after PGA > $0.25 \mathrm{~g}$.

To check the relevance between actual shake table motions and target motions, achieved PGAs were compared with the target ones. Target and achieved PGAs and the ratios of the achieved PGAs to target ones were listed in Table 4. One can see that the ratios were within 0.99 1.09 for all cases, indicating that the achieved and target values are quite matched.

\section{Validation of Test Model against Prototype}

The test model is assumed to provide a realistic representation of the prototype bridge response. However, to simplify the construction, several adjustments were made to the test model comparing to theoretical model which is exactly scaling down from the prototype bridge structure. These adjustments included the following: (1) the plate thickness of the tower was enlarged to $80 \mathrm{~mm}$; (2) the deck was a regular box section with $10 \mathrm{~mm}$ thick steel plate to substitute the streamlined, flat, thin-walled steel box, following the scale factors of flexural stiffness; (3) the number of cables was condensed from 68 to 16 to simplify the construction. Therefore, preliminary linear analysis was performed to check the accuracy of the test model representing theoretical model at linear stage.

Two analytical models were conducted for preliminary analysis based on OpenSees (open system for earthquake engineering simulation) [21]: Model A, analytical model for test model, and Model B for theoretical model. For both models, the tower, piers, and the deck were modeled using linear-elastic element with P-Delta effects included. The stay cables were modeled using truss elements and sag effect was accounted for based on Ernst's equivalent elastic modulus concept [22]. Connections of deck-piers and deck-tower are free for longitudinal floating system while being restrained for transverse direction. Since the tower and bents of the test model were fixed on the shake tables and the soil-structure interaction effect was neglected, fixed constraint was set to the tower and the bents for two models.

Table 5 lists comparisons between theoretical model and test model with 1st and 2nd longitudinal modal periods and time-history analysis results. In Table 5, the 1st mode for two models was longitudinal vibration of the deck while 2 nd mode was longitudinal vibration of the tower, and the input ground motion used for time-history analysis was Case 2 from Table 4. From Table 5, one can see that the maximum error of the natural period between the test model and the theoretical model was within $15 \%$ and the maximum error of seismic response was within $10 \%$.

\section{Test Results}

5.1. Observed Damaged. The observed damage was mainly from the concrete cracks and concrete spalling of the tower while the deck, cables, and bents were visually undamaged. The development of observed cracks at RC tower sections subjected to increasing PGA was shown in Table 6 and Figure 7. One can see that severe structural damage occurred at the tower of the model including parallel concrete cracks from the bottom to nearly half height of the tower, concrete spalling, and exposed bars at top tower $0.2 \mathrm{~m}$ above the section where two skewed legs intersect. When PGA reached $0.8 \mathrm{~g}$, sudden large noise was produced at the time that the concrete spalls and large permanent rotation was observed at top tower after the test. Out of safety consideration and to prevent collapse of the model, no TCU052 waves with larger PGA were applied to the test model after PGA $=0.8 \mathrm{~g}$.

An immediate survey was conducted concerning the cause of concrete spalling at Section C-C as PGA $=0.8 \mathrm{~g}$. It was due to abrupt change of cross section at Section C-C where stress concentration was induced, as shown in Figure 8.

5.2. Model Period. Along with damage observation, model period shift of the test model was also detected during the 
TABLE 5: Comparison of the test model and theoretical model.

\begin{tabular}{|c|c|c|c|}
\hline Items & Theoretical model & Test model & errors \\
\hline \multicolumn{4}{|l|}{ Modal analysis } \\
\hline 1st longitudinal model period (s) & 1.335 & 1.149 & $-13.9 \%$ \\
\hline 2nd longitudinal model period (s) & 0.630 & 0.545 & $-13.5 \%$ \\
\hline \multicolumn{4}{|l|}{ Time history analysis } \\
\hline Peak displacement at tower top (m) & 0.0273 & 0.0284 & $4.0 \%$ \\
\hline Peak displacement at deck end (m) & 0.0368 & 0.0331 & $-10.0 \%$ \\
\hline Peak bending moment at tower bottom $(\mathrm{kN} \cdot \mathrm{m})$ & 52.87 & 56.5 & $6.8 \%$ \\
\hline
\end{tabular}

TABLE 6: Observed damage during the test.

\begin{tabular}{|c|c|c|}
\hline PGA & Damage height & description \\
\hline $0-0.25 \mathrm{~g}$ & - & No damage. \\
\hline $0.30 \mathrm{~g}$ & $H=0.65 \mathrm{~m}$ & First crack appeared at the bottom of tower leg. \\
\hline \multirow{2}{*}{$0.30 \sim 0.50 \mathrm{~g}$} & $H=0.65 \mathrm{~m}$ & First crack extended to gradually form a circle. \\
\hline & $H=0.80 \sim 1.20 \mathrm{~m}$ & Several parallel cracks appeared just above the first crack. \\
\hline $0.50 \mathrm{~g} \sim 0.60 \mathrm{~g}$ & $H=0.80 \sim 1.20 \mathrm{~m}$ & Cracks extended horizontally. \\
\hline \multirow[t]{2}{*}{$0.6 \sim 0.70 \mathrm{~g}$} & $H=1.4 \mathrm{~m} \sim 3.5 \mathrm{~m}$ & $\begin{array}{l}\text { Several parallel cracks appeared and were distributed in parallel at a nearly equal } \\
\text { distance of tower width (around } 0.35 \mathrm{~m} \text { ). }\end{array}$ \\
\hline & $H=5.8 \mathrm{~m}$ & $\begin{array}{l}\text { Cracks appeared at top tower } 0.2 \mathrm{~m} \text { above the section where two skewed legs } \\
\text { intersect (Section C-C in Figure 3). }\end{array}$ \\
\hline $0.75 \mathrm{~g}$ & $H=5.8 \mathrm{~m}$ & Cracks extended and penetrated Section C-C. \\
\hline $0.80 \mathrm{~g}$ & $H=5.8 \mathrm{~m}$ & $\begin{array}{l}\text { Considerable concrete spalling and exposed longitudinal bars were observed at } \\
\text { Section C-C. }\end{array}$ \\
\hline
\end{tabular}

test. The stiffness of concrete structure decreased as structural damage occurred and developed. Therefore, modal periods, related to structural stiffness, can be used as a stiffness degradation index of the tested model due to structural damage under earthquake excitation. Based on white noise excitation results, model periods were determined from plots of the Fast Fourier Transform (FFT) utilizing acceleration at tower top and table acceleration.

Figure 9 shows the changes of the first and second modal period of the test model after applying TCU052 waves with varying PGA. Based on FFT results, the first mode of the test model is longitudinal vibration of the deck and the second mode is longitudinal vibration of the tower coupled with vertical vibration of the deck. From Figure 9, the second modal period gradually increased three times, namely, at PGA $=0.45 \mathrm{~g}, 0.7 \mathrm{~g}$, and $0.75 \mathrm{~g}$, which fit in with the observed damage in Table 6 . The first modal period slightly increased only when penetrating cracks occurred at Section $\mathrm{C}-\mathrm{C}$ at PGA $=0.75 \mathrm{~g}$. After the test, the period for the first and second longitudinal mode was $1.06 \mathrm{~s}$ and $0.70 \mathrm{~s}, 3 \%$ and $10 \%$ longer than that before the test, respectively. The increased modal periods reflected stiffness degradation of the model as damage of tower occurred and accumulated during the test.

5.3. Acceleration and Displacement Response. Figure 10 presents measured maximum longitudinal acceleration and displacement at tower top and at deck end. From Figure 10(a), acceleration at tower top and that at deck end both increased linearly as PGA increased for most cases. From Figure 10(b), the displacement at tower top increased almost linearly with increasing PGA when PGA $\leq 0.70 \mathrm{~g}$. But when concrete spalling appeared at PGA $=0.8 \mathrm{~g}$, the tower top suddenly went through large displacement response, almost twice that at $\mathrm{PGA}=0.75 \mathrm{~g}$. Deck displacement linearly increased with increasing PGA, revealing that cracks or concrete spalling of the tower negligibly influenced deck displacement response.

5.4. Cable Response. Figure 11 shows tension force envelope of $\mathrm{Cl} \sim \mathrm{C} 4$. When $\mathrm{PGA}<0.70 \mathrm{~g}$, the maximum and minimum tension forces of $\mathrm{C} 1 \sim \mathrm{C} 4$ changed in a linear manner as PGA increased. However, when PGA $=0.7 \mathrm{~g}$, the minimum tension force of $\mathrm{C} 3$ and $\mathrm{C} 4$ almost reached 0 and no longer decreased as PGA increased. As cable forces dropped to 0, the cables provided no stiffness to support the deck, reflecting that cable relaxation occurred for $\mathrm{C} 3$ and $\mathrm{C} 4$ during the test. When PGA $>0.7 \mathrm{~g}$, little change was observed as PGA increased for the minimum tension force of $\mathrm{C} 1$ and $\mathrm{C} 2$ and maximum tension force of all cables, clearly indicating influence of cable relaxation on cable force response. When PGA $=0.8 \mathrm{~g}$, the maximum tension force of $\mathrm{C} 1, \mathrm{C} 3$, and $\mathrm{C} 4$ reached about twice the initial cable force, showing large variation of cable forces during the test.

\section{Posttest Analysis Results}

6.1. Analytical Model for Posttest Analyses. To determine the adequacy of existing nonlinear analytical techniques in estimating the seismic response of cable-stayed bridges, 

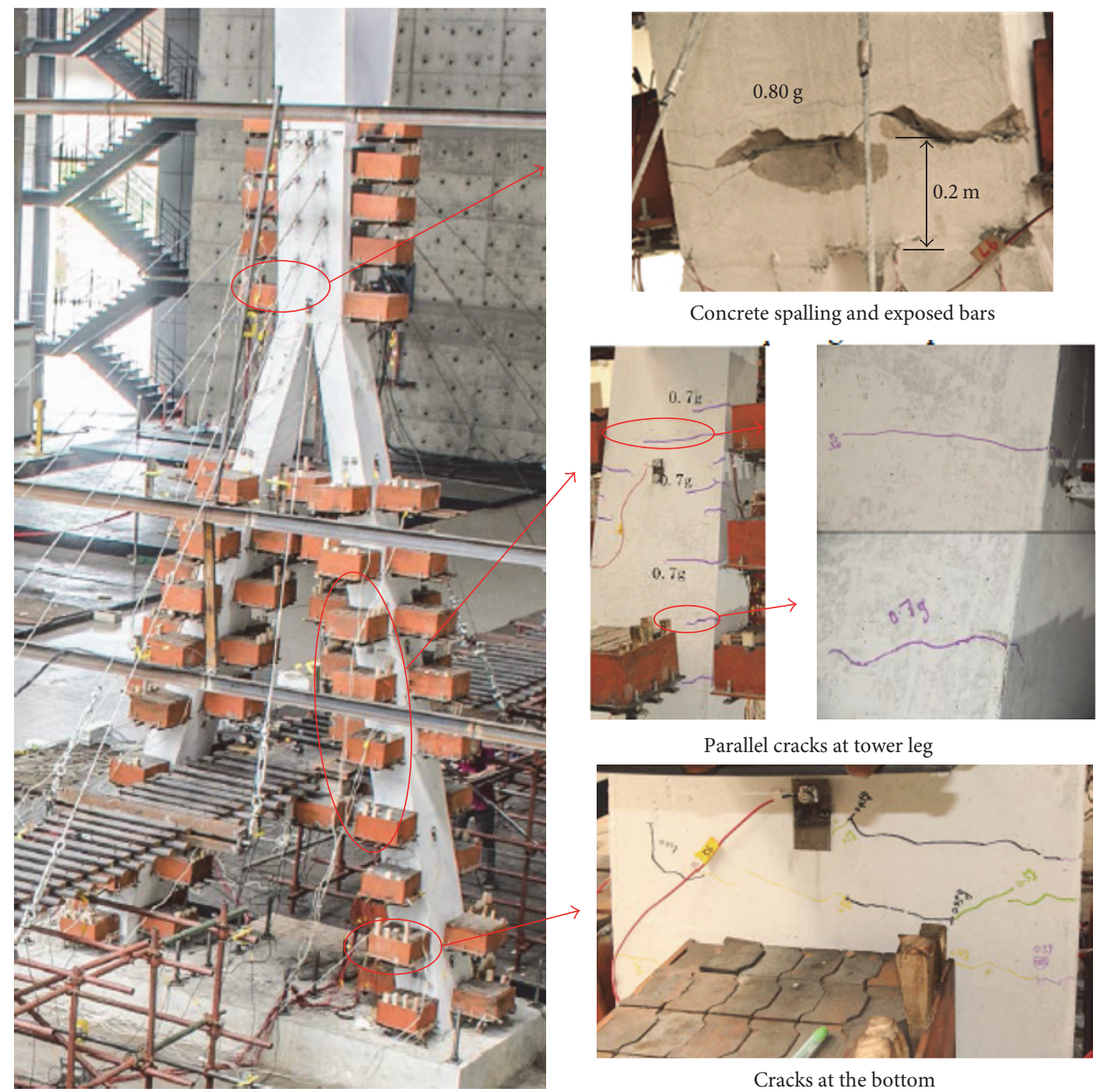

FIgURE 7: Observed seismic damage of the bridge model.

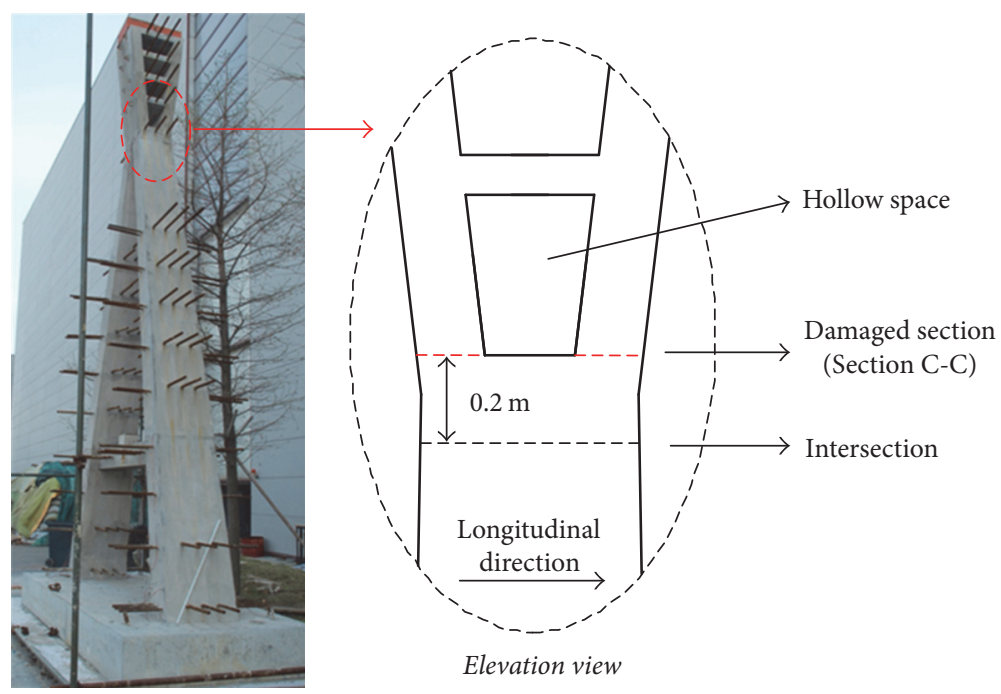

Figure 8: Configuration of Section C-C. 


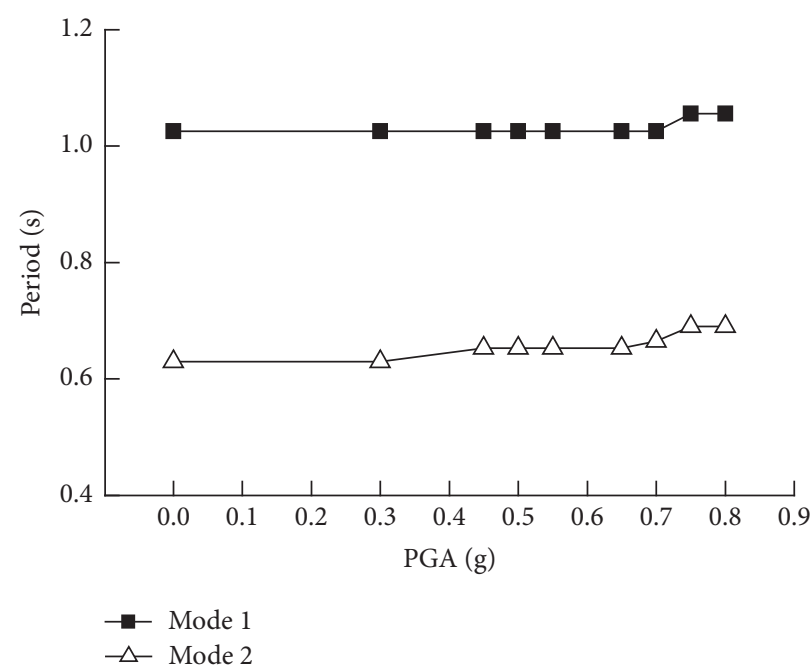

FIgURE 9: Period shifts of first and second longitudinal modes.

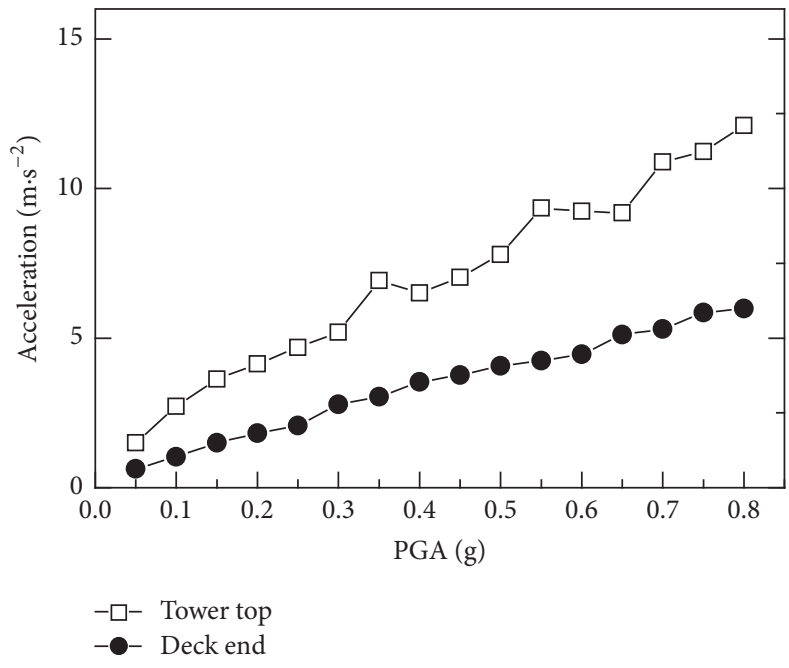

(a) Acceleration response

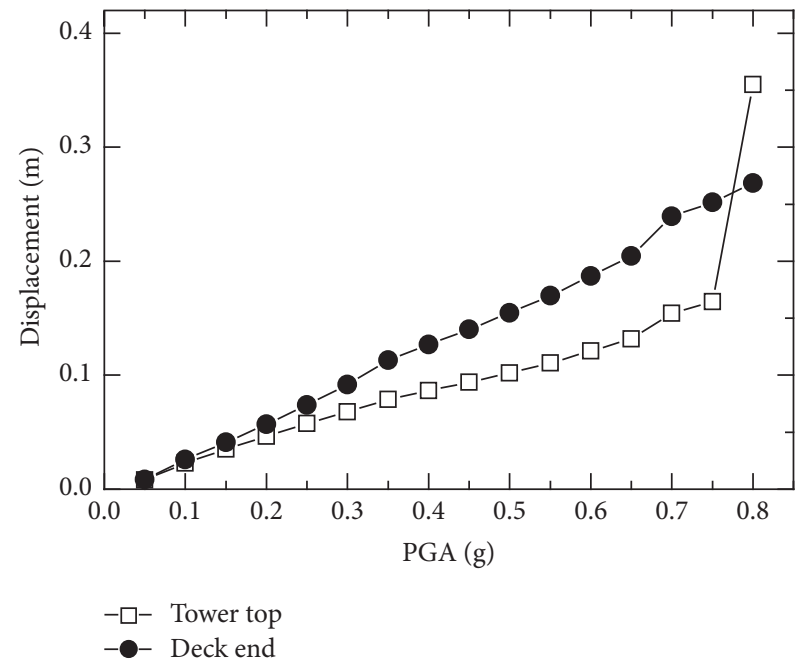

(b) Displacement response

Figure 10: Measured peak acceleration and displacement response of the model.

one sophisticated model, Model C, was conducted for the test model based on OpenSees. Both Nazmy and AbdelGhaffar [23] and Ren and Obata [24] recommended the following nonlinear characteristics when modeling large long cable-stayed bridges for seismic analyses: (1) sag effect of inclined cables, (2) combined axial load and bending moment interaction effect of towers and deck, (3) large displacement effect of the structure, and (4) material nonlinearity. These nonlinearities were modeled in Model C. Besides, cable relaxation, detected in the experiments, was also considered. Similar to Model A, fixed constraint was set to the tower and the bents for two models, ignoring the soil-structure interaction. The following shows the modeling details of different parts of the model, namely, tower and bents, superstructure, cables, and bearings.
6.1.1. Tower and Bents Model. To account for material nonlinearity and axial force-moment interaction effect, the tower and bents were modeled using nonlinear beam-column elements whose cross section was discretized into unidirectional confined concrete, unconfined concrete, and steel fibers. Both confined and unconfined concrete fibers were represented using the uniaxial Kent-Scott-Park model [25] with degraded linear unloading/reloading stiffness. The steel fibers were represented using a bilinear hysteretic model with kinematic strain hardening. The concrete fibers were at a rectangular patch. As an example, Section A-A contained 1, 536 concrete fibers and 28 longitudinal bar fibers.

6.1.2. Superstructure Model. During the test, no damage occurred at superstructure. Therefore, the superstructure is 

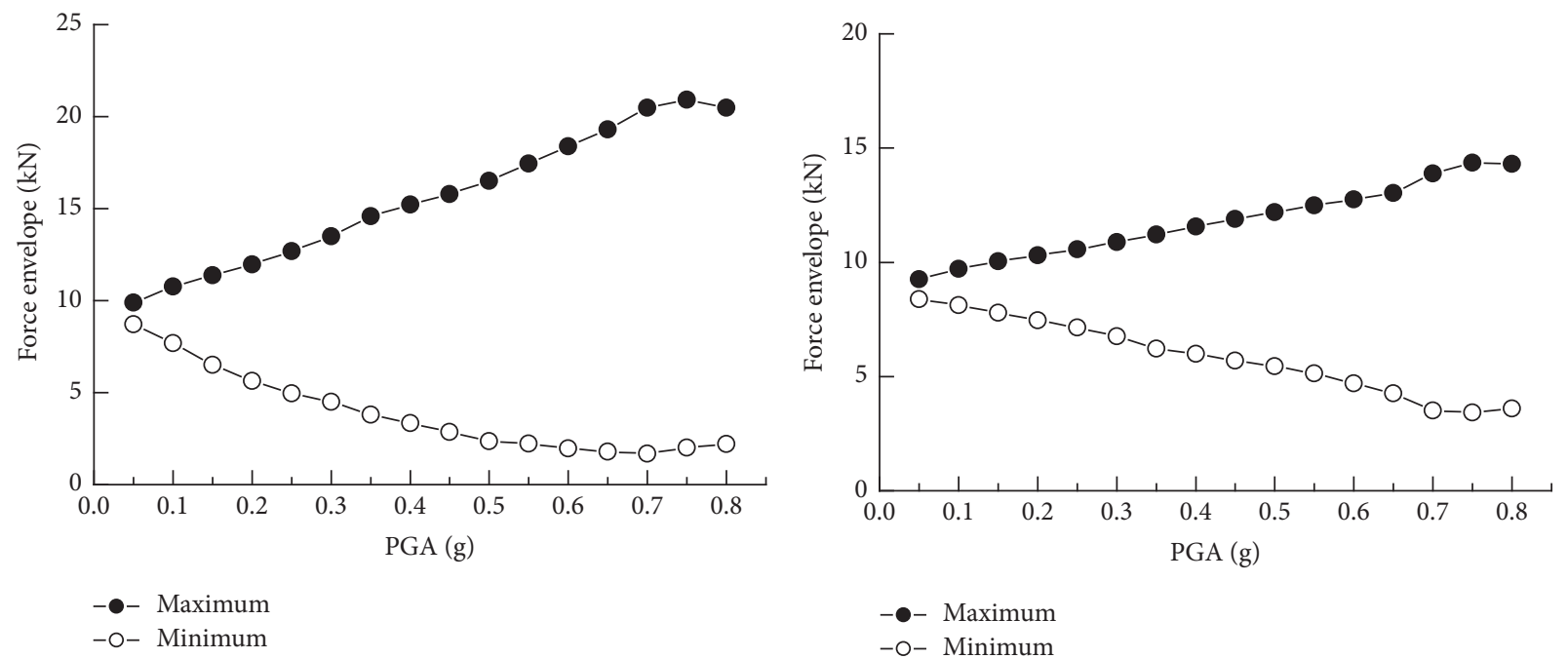

(a) $\mathrm{C} 1$

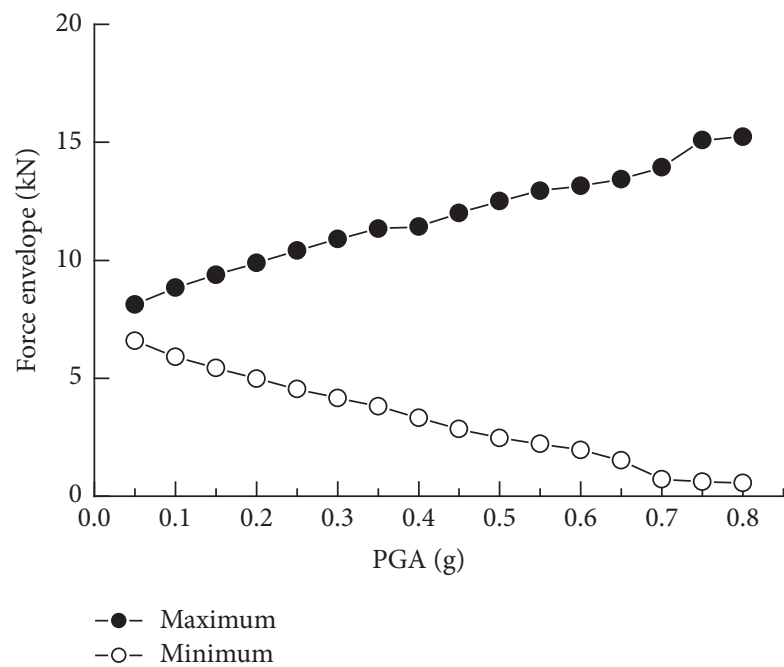

(c) $\mathrm{C} 3$

(b) $\mathrm{C} 2$

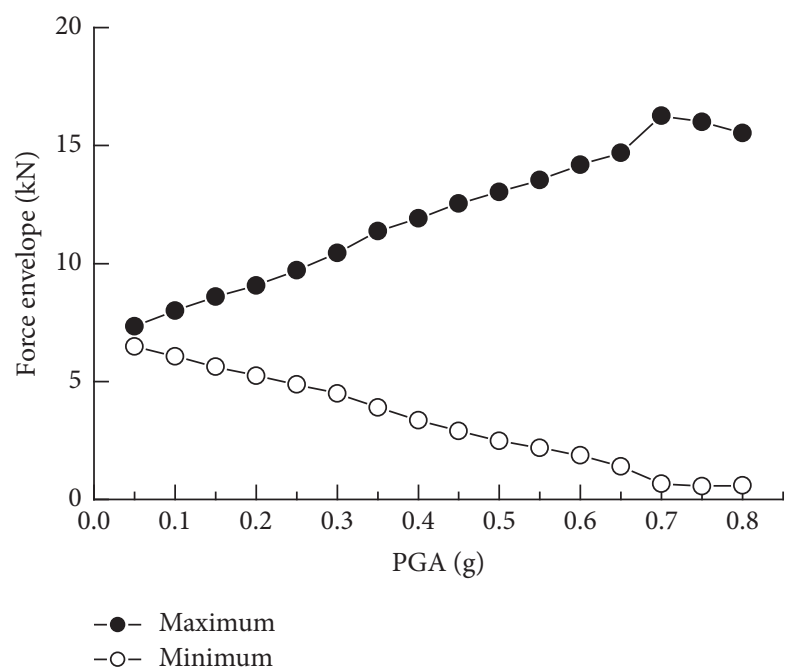

(d) $\mathrm{C} 4$

FIGURE 11: Cable force envelope of test results.

expected to remain linear during earthquake and was modeled using linear-elastic element. However, its axial forcemoment interaction and large displacement effect were taken into account.

6.1.3. Cable Model. Two sources of nonlinearity were included in the cable modeling: sag effects and cable relaxation. Sag effects were approximately taken into account based on Ernst's equivalent elastic modulus [22]. In fact, elastic modulus of cables changes with varying cable force during the excitation. However, constant elastic modulus from dead loads was adopted instead since changing cable force had limited influence on the cable stiffness, as indicated by Zárate and Caicedo's work [26]. Cable relaxation was considered using no-compression material so that cables function only in tension state. Besides, cables are prestressed under dead-load state, which is considered by applying initial strain to cable material so that the cable force resists at prestressed value at zero applied force.
6.1.4. Bearing Model. Longitudinal sliding bearings were used to connect the deck to the tower and piers. In longitudinal direction, friction effects of sliding bearings were modeled with an elastic-plastic material and the initial stiffness was calculated as $K=267 \mathrm{kN} / \mathrm{m}$ based on the geometry of the bearing. In transverse and vertical direction, the connections between deck-pier and deck-tower were set fixed since transverse displacement of the deck was restrained by the restrainers and vertical movement of deck end at piers was restrained by gate-style frames (see Figure 5).

6.1.5. Completed Model. Figure 12 shows general configuration of Model C. After modeling, Model C had totally 278 nodes, 108 nonlinear beam-column elements, 109 linearelastic beam-column elements, and 16 cable elements. Before nonlinear seismic analysis, dead load was applied to the three FEM models prior to nonlinear dynamic analysis so that nonlinear seismic analysis starts from the equilibrium 


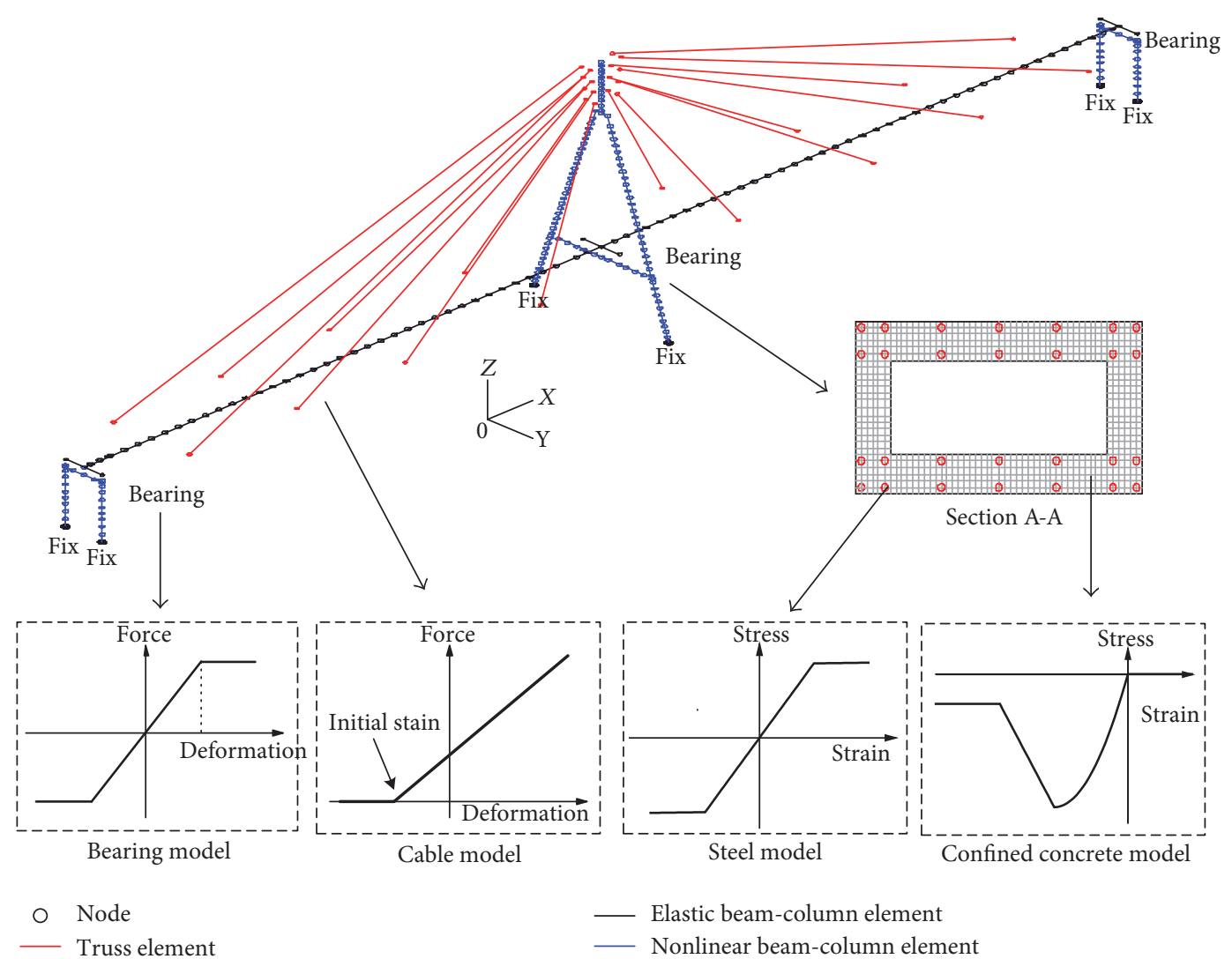

Figure 12: FEM model of Model C.

configuration of dead loads $[23,24] .5 \%$ inherent damping was accounted for using Rayleigh damping based on 1st and 2nd longitudinal vibration period.

\subsection{Validation of Model C}

6.2.1. Acceleration and Displacement Response. OpenSees analysis of Model $\mathrm{C}$ was conducted to evaluate its ability to reproduce the measured test results. Figures 13 and 14 show comparison of acceleration and displacement histories at tower top and at deck end between measured and numerical result, respectively. In addition, Table 7 shows the comparisons of peak displacement results between measured and numerical results.

From Figures 13 and 14, it can be seen that though numerical results of Model C slightly deviated from the test results, numerical results catch the main features of the measured results and the shapes of the time histories fit in well for PGA $<0.8 \mathrm{~g}$. When PGA $=0.8 \mathrm{~g}$, numerical acceleration histories agreed with test results while numerical displacement histories failed to catch tower permanent displacement at $t=9 \mathrm{~s}$ when concrete spalling occurred of test model.

As seen in Table 7, for deck displacement, the correlation between measured and numerical results was good with maximum error less than $10 \%$. For tower displacement, numerical results and measured results agreed quite well at low PGA levels (PGA $<0.15 \mathrm{~g}$ ) with maximum error less than $10 \%$, but numerical results were slightly overestimated as PGA increased $(0.2 \mathrm{~g} \leq \mathrm{PGA} \leq 0.75 \mathrm{~g})$ with maximum error up to $46 \%$. And when PGA $=0.8 \mathrm{~g}$, numerical results failed to catch the suddenly increased tower displacement of measured results.

The disagreement between measured and numerical results may be from the fact that the concrete model used in the numerical model might deviate from the actual stressstain relationship of microconcrete. But based on the overall satisfactory correlation between the measured and calculated results, it was concluded that Model $\mathrm{C}$ adequately simulated the acceleration and displacement response of the test model.

6.2.2. Cable Force Response. Figure 15 shows a representative sample of measured and numerical cable force histories for C3 which went through cable relaxation during the test. Table 8 shows comparison of maximum and minimum cable force between measured and numerical results. In Figure 15 and Table 8 , the cable forces were normalized by the pretension value at completed state of C3 $(8.75 \mathrm{kN})$. From Figure 14, it can be seen that the numerical results clearly catch the cable relaxation at $\mathrm{PGA}=0.8 \mathrm{~g}$ when minimum cable force drops to zero. And as seen in Table 8, the numerical results agreed with measured maximum cable force for all PGA levels with maximum difference less than $15 \%$, while the difference of minimum tension force was slightly larger between test results and numerical results, with 

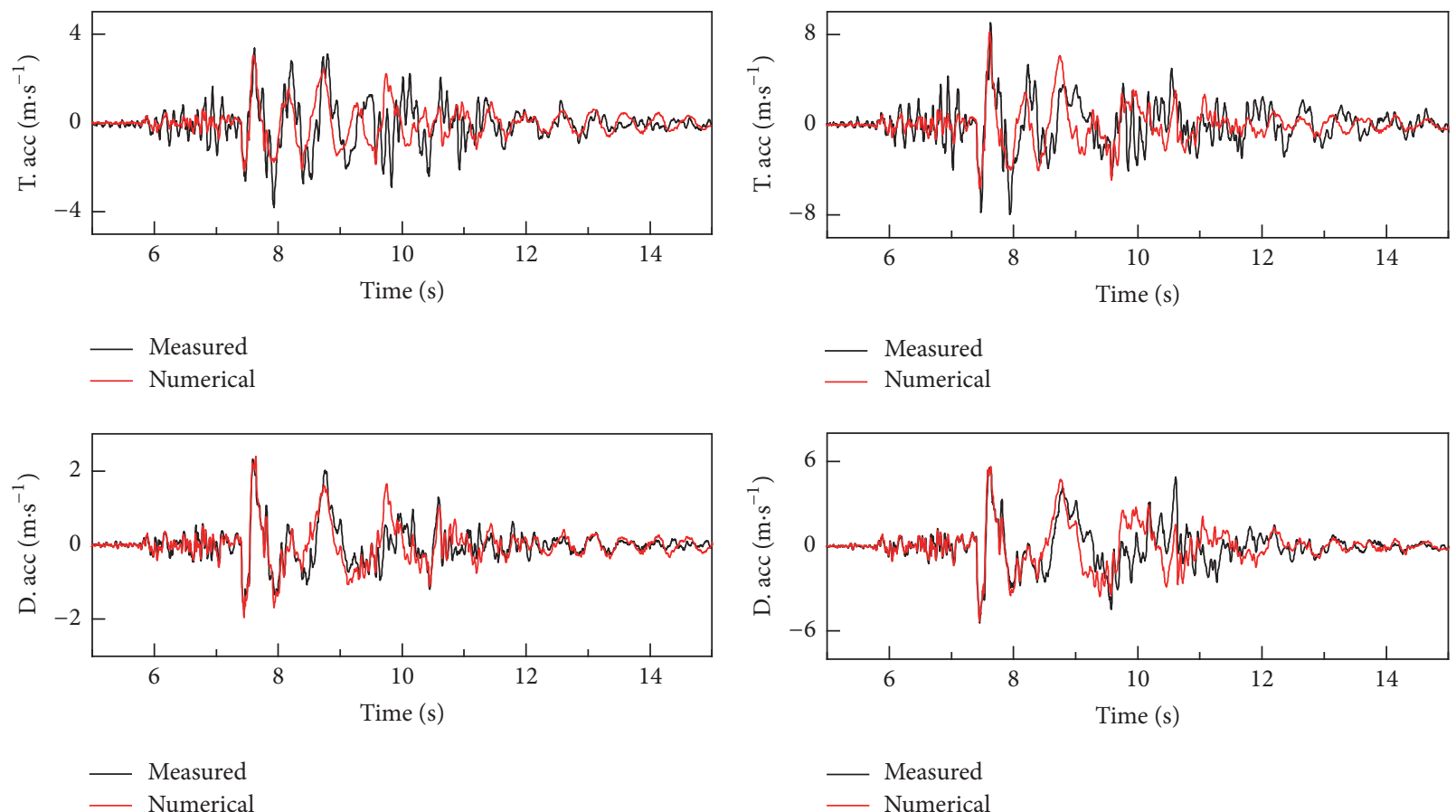

(a) $\mathrm{PGA}=0.15 \mathrm{~g}$
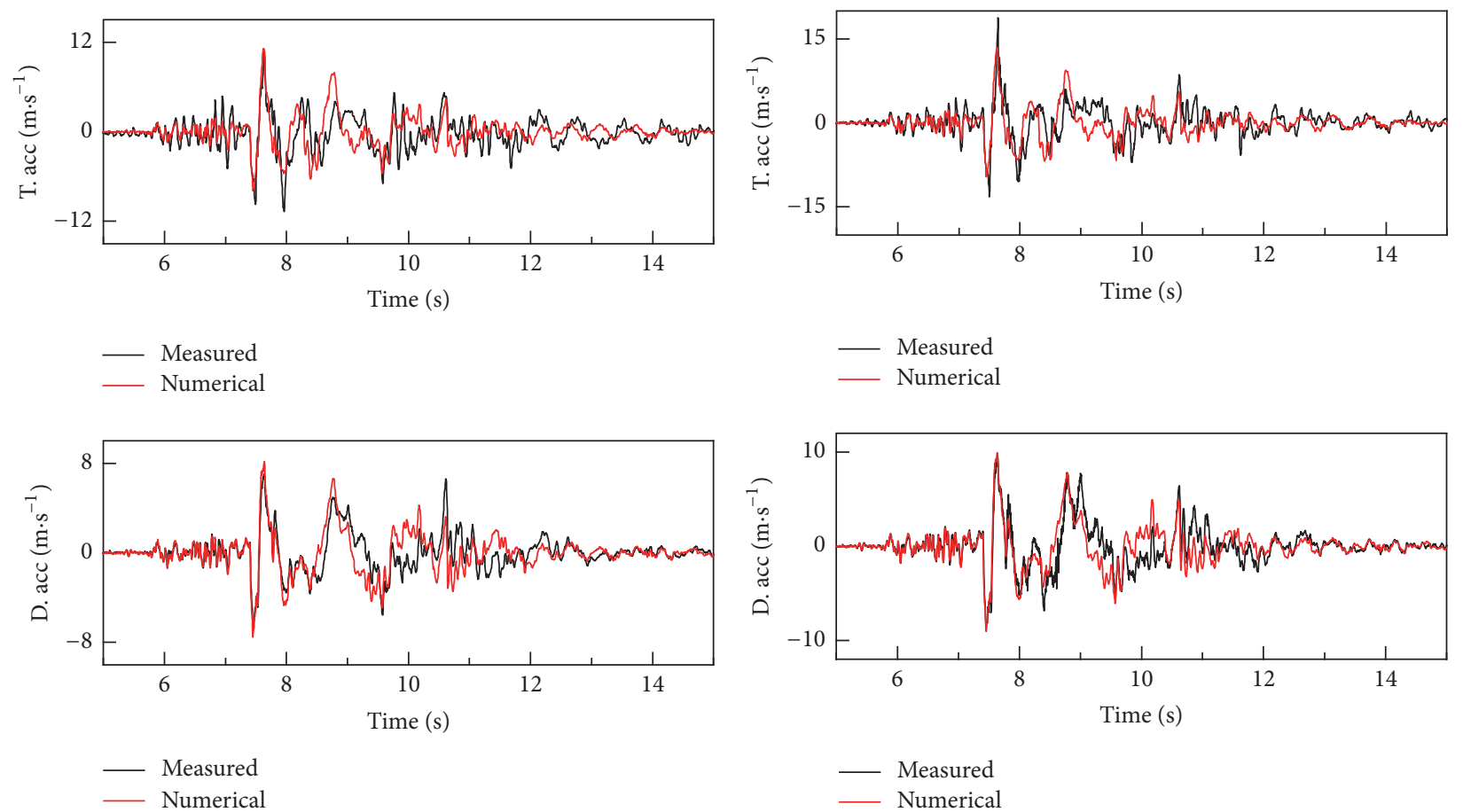

(c) $\mathrm{PGA}=0.60 \mathrm{~g}$

(d) $P G A=0.80 \mathrm{~g}$

FIGURE 13: Comparisons between measured and numerical results of acceleration histories at tower top and deck end.

maximum difference around $25 \%$. Based on the comparison, the numerical model was able to capture large variation of cable tension force and cable relaxation.

6.2.3. Steel Strain Response. Figure 16 shows measured and numerical results of maximum steel strain response for the tower in order to verify that numerical model duplicates the observed damage of the test model. For the test model, steel strain gauges were placed only at Sections A-A and B-B and no stain gauges were available at Section $\mathrm{C}-\mathrm{C}$. Thus, only measured steel strain at Sections A-A and B-B was provided in Figure 16. 

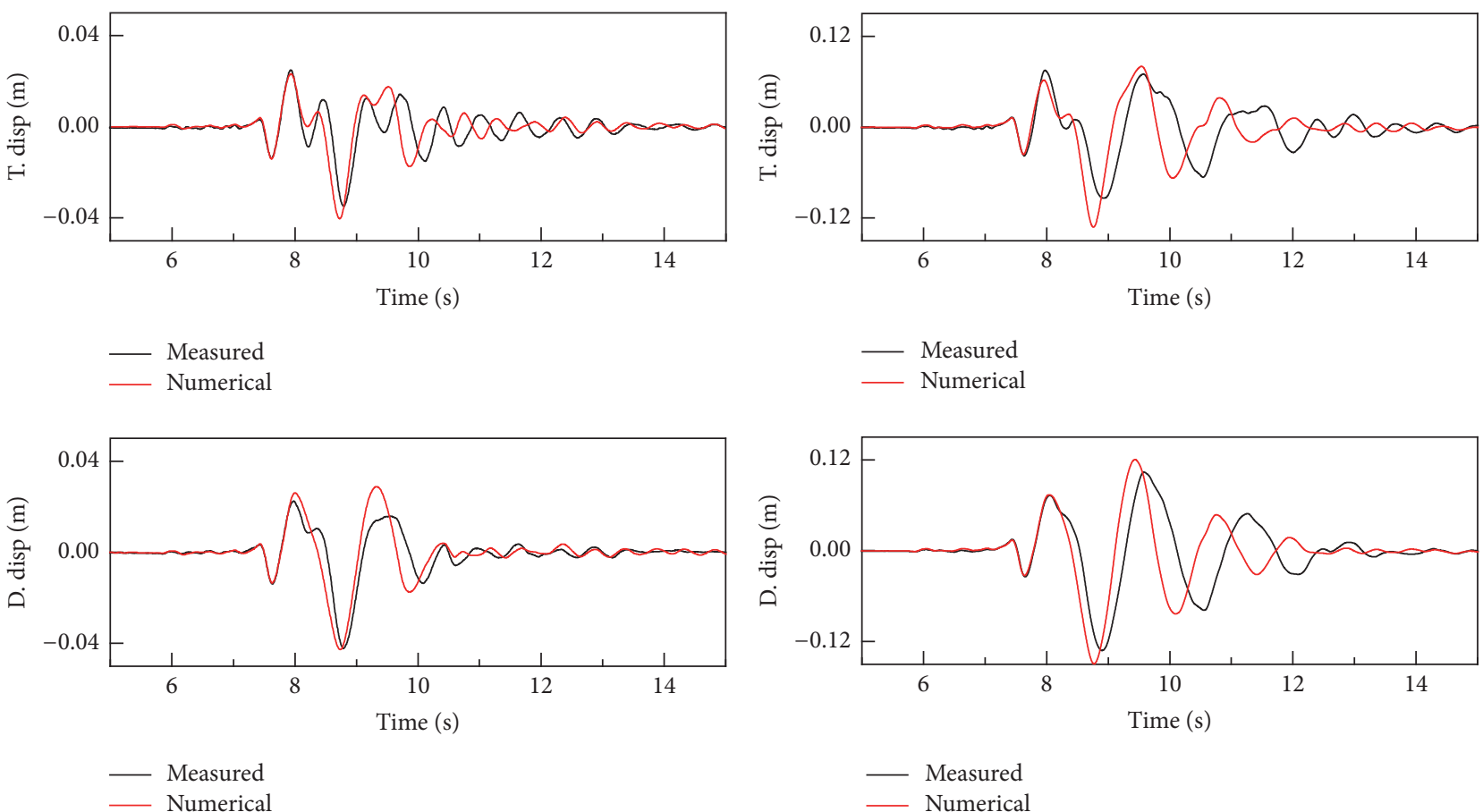

(a) $\mathrm{PGA}=0.15 \mathrm{~g}$

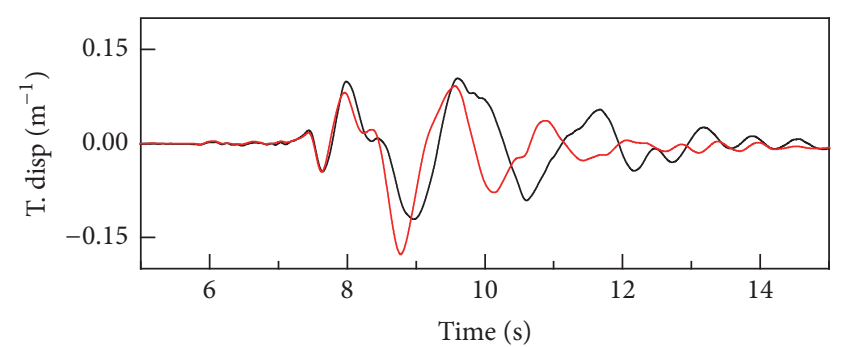

(b) $\mathrm{PGA}=0.45 \mathrm{~g}$
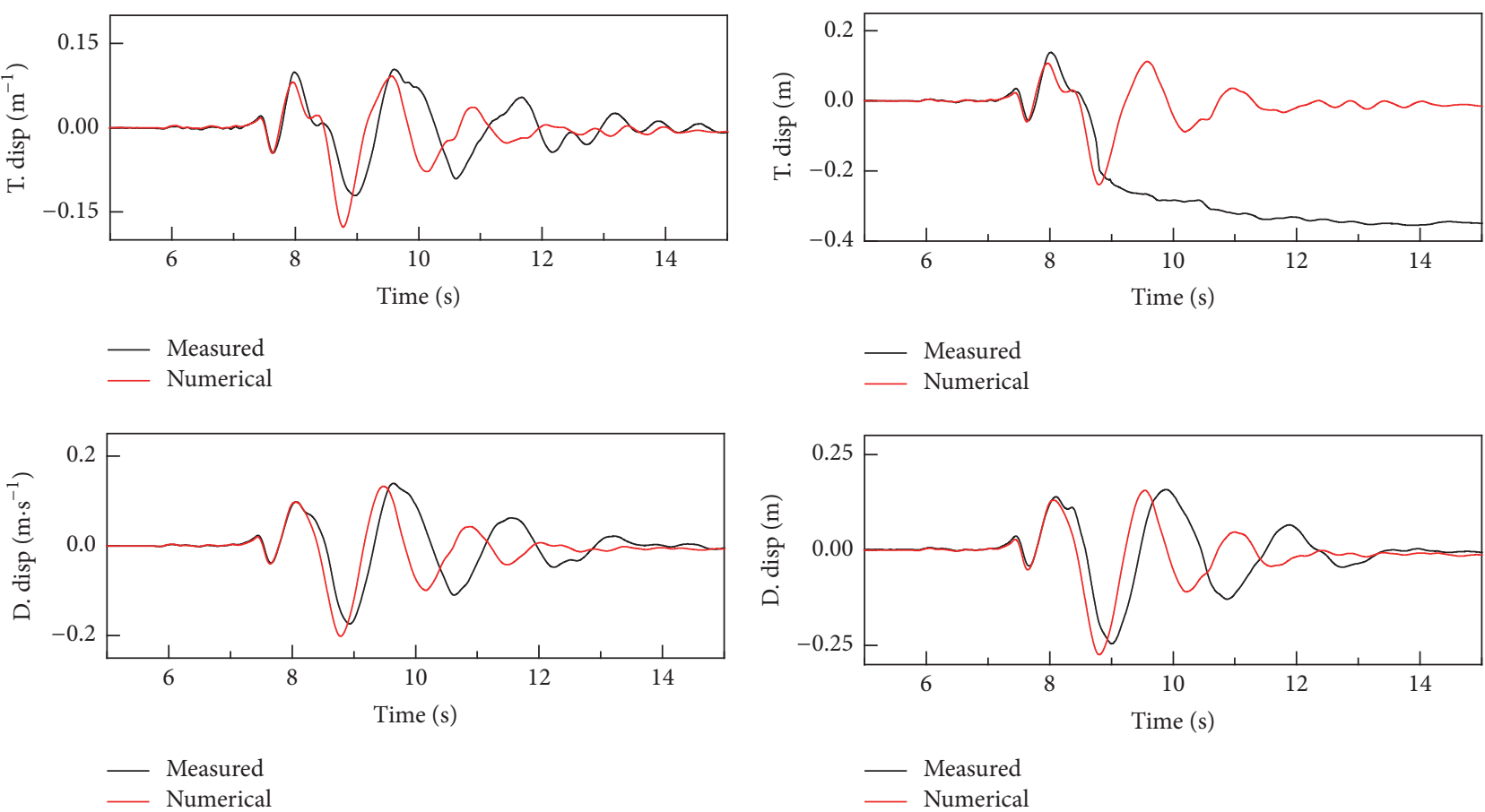

(c) $\mathrm{PGA}=0.60 \mathrm{~g}$

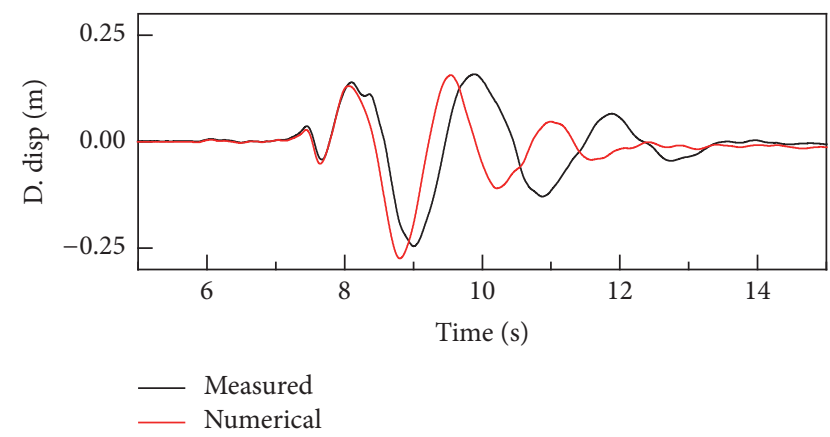

(d) $P G A=0.80 \mathrm{~g}$

FIGURE 14: Comparisons between measured and numerical results of displacement histories at tower top and deck end.

From Figure 16, it can be seen from numerical steel stain envelop that before longitudinal steel yielded (PGA $<0.4 \mathrm{~g}$ ), the maximum strain occurred at tower bottom, which agreed with observation during the test that the first cracks occurred at this section. The longitudinal steel first yielded when PGA
$=0.4 \mathrm{~g}$ at Section A-A (height $=0.65 \mathrm{~m})$ and Section BB (height $=2 \mathrm{~m}$ ). At this PGA level, steel stains at lower tower almost reached yield limit. After steel first yielded (PGA $>0.4 \mathrm{~g})$, steel strain at lower tower and middle tower increased almost linearly as PGA increased at a controllable 


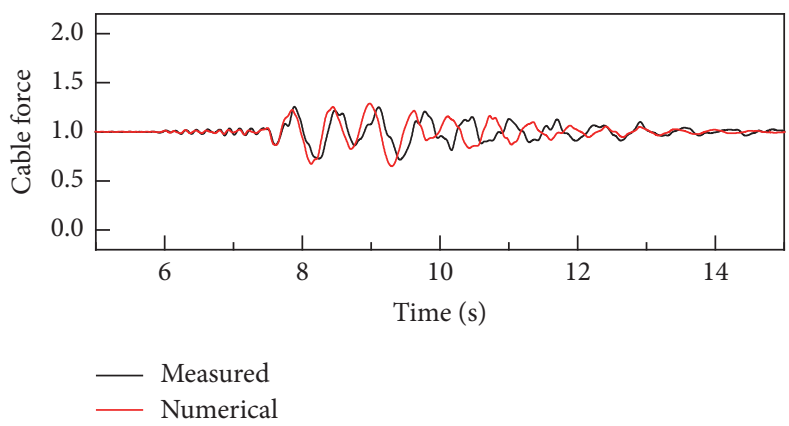

(a) $\mathrm{PGA}=0.15 \mathrm{~g}$

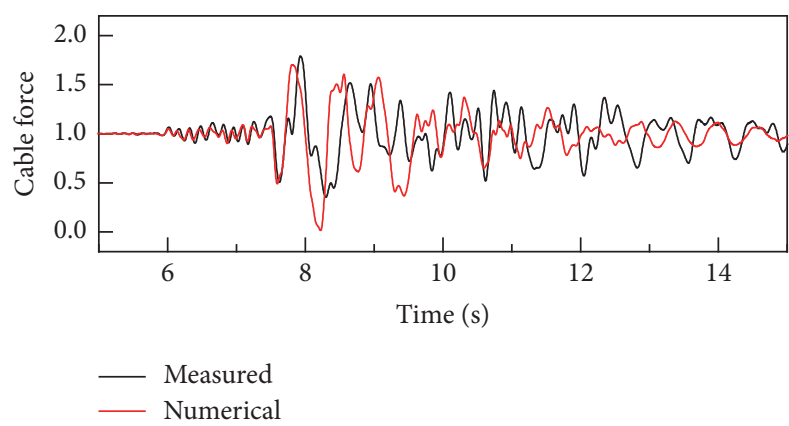

(c) $\mathrm{PGA}=0.6 \mathrm{~g}$

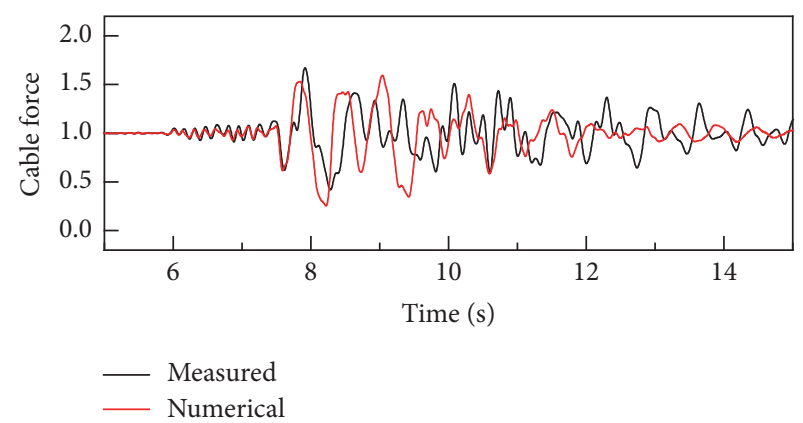

(b) $P G A=0.45 \mathrm{~g}$

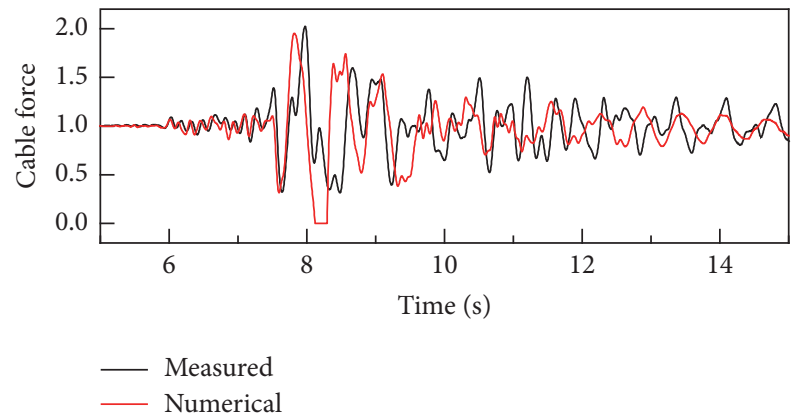

(d) $P G A=0.80 \mathrm{~g}$

FIGURE 15: Comparisons of normalized cable force histories between measured and numerical results (C3).

TABLE 7: Comparisons of maximum displacement between measured and numerical results.

\begin{tabular}{|c|c|c|c|c|c|c|}
\hline \multirow{2}{*}{ PGA } & \multicolumn{3}{|c|}{ Tower top displacement (m) } & \multicolumn{3}{|c|}{ Deck end displacement (m) } \\
\hline & Test results & Numericalresults & Error & Test results & Numericalresults & Error \\
\hline 0.05 & 0.0082 & 0.008931 & $8.91 \%$ & 0.0085 & 0.007804 & $-8.19 \%$ \\
\hline 0.1 & 0.0228 & 0.02586 & $13.42 \%$ & 0.0261 & 0.027044 & $3.62 \%$ \\
\hline 0.15 & 0.035 & 0.043353 & $23.87 \%$ & 0.0413 & 0.047237 & $14.38 \%$ \\
\hline 0.2 & 0.0465 & 0.059795 & $28.59 \%$ & 0.0568 & 0.066117 & $16.40 \%$ \\
\hline 0.25 & 0.0576 & 0.077512 & $34.57 \%$ & 0.0737 & 0.086395 & $17.23 \%$ \\
\hline 0.3 & 0.0679 & 0.091692 & $35.04 \%$ & 0.0917 & 0.10319 & $12.53 \%$ \\
\hline 0.35 & 0.0787 & 0.10177 & $29.31 \%$ & 0.1133 & 0.113957 & $0.58 \%$ \\
\hline 0.4 & 0.0865 & 0.11591 & $34.00 \%$ & 0.1269 & 0.130522 & $2.85 \%$ \\
\hline 0.45 & 0.0937 & 0.12882 & $37.48 \%$ & 0.1403 & 0.145473 & $3.69 \%$ \\
\hline 0.5 & 0.1019 & 0.14146 & $38.82 \%$ & 0.1547 & 0.160204 & $3.56 \%$ \\
\hline 0.55 & 0.1108 & 0.15357 & $38.60 \%$ & 0.1698 & 0.174496 & $2.77 \%$ \\
\hline 0.6 & 0.1212 & 0.17336 & $43.04 \%$ & 0.1871 & 0.197462 & $5.54 \%$ \\
\hline 0.65 & 0.1318 & 0.18981 & $44.01 \%$ & 0.2044 & 0.216463 & $5.90 \%$ \\
\hline 0.7 & 0.1542 & 0.21695 & $40.69 \%$ & 0.2393 & 0.248249 & $3.74 \%$ \\
\hline 0.75 & 0.1644 & 0.228 & $38.69 \%$ & 0.2517 & 0.261367 & $3.84 \%$ \\
\hline 0.8 & 0.355 & 0.23537 & $-33.70 \%$ & 0.2687 & 0.269654 & $0.36 \%$ \\
\hline
\end{tabular}

range. For example, the maximum steel strain of Sections $\mathrm{A}-\mathrm{A}$ and $\mathrm{B}-\mathrm{B}$ was about 3 times the yield strain when PGA $=0.8 \mathrm{~g}$. Meanwhile, the yielding sections at middle tower extended to higher height as PGA increased, showing related damage process of the test model. When PGA $=0.8 \mathrm{G}$, the highest section with yielding steel at middle tower was at $3.4 \mathrm{~m}$, almost at half height of the tower, agreeing with observation during the test. At top tower, the yielding section only occurred at Section C-C where cross section changed abruptly and its steel stain increased substantially after first yielding at $\mathrm{PGA}=0.4 \mathrm{~g}$. The maximum steel strain was 15 times the yield stain when PGA $=0.8 \mathrm{~g}$, which accordingly depicted concrete spalling at this section.

For Sections A-A and B-B, numerical steel stain agreed quite well with measured results when PGA $<0.35 \mathrm{~g}$. However, after steel yielded at PGA $=0.4 \mathrm{~g}$, discrepancy of 

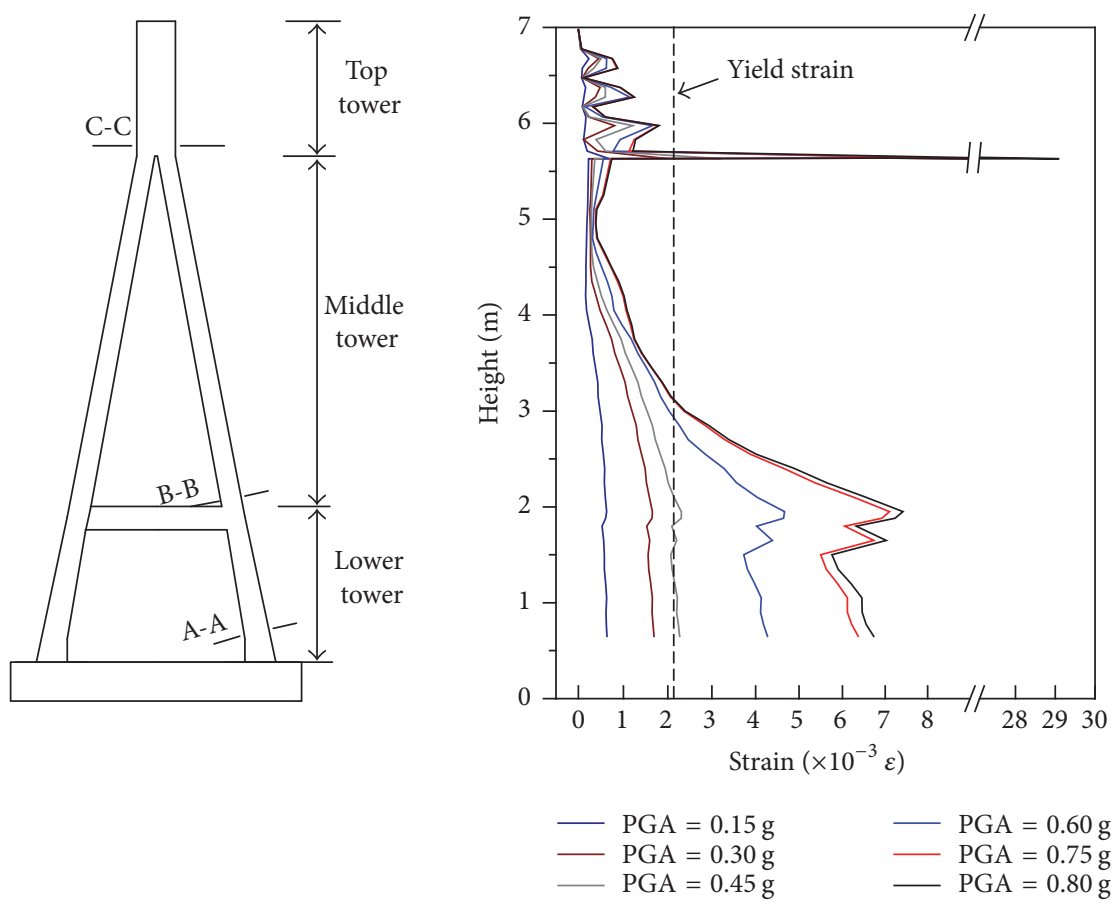

Numerical steel stain envelop along tower height

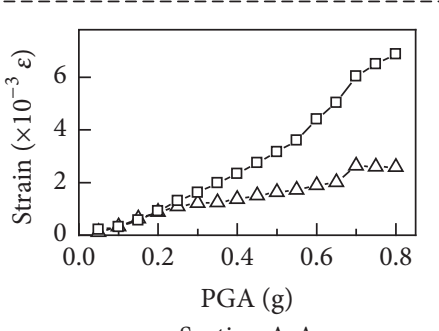

Section A-A

$-\Delta-$ Measured

$-\square-$ Numerical

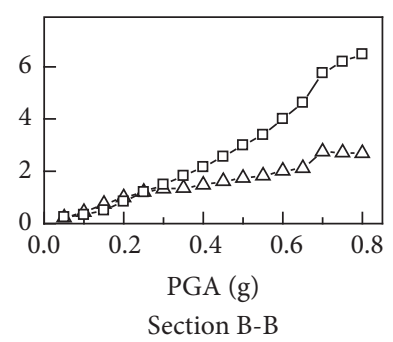

$-\Delta-$ Measured

- - Numerical

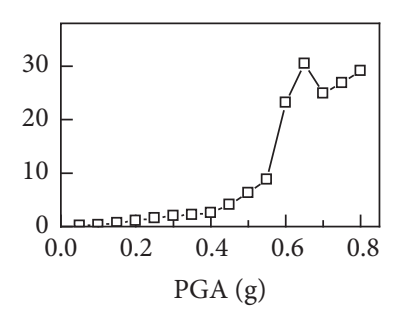

Section C-C

$-\square-$ Numerical

FIgURE 16: Measured and numerical results of maximum longitudinal steel strain response for the tower.

numerical and measured results was observed since steel stain gauges of the test model lose proper function at high strains $\left(>2 \times 10^{-3} \varepsilon\right)$.

From the above discussion, Model C overall reflected test model of the measured acceleration and displacement response, cable tension force, and the observed damage with good agreement. It is concluded that, by modeling several nonlinearities of different elements of cable-stayed bridges, Model C is able to simulate the elastic-plastic behavior of the cable-stayed bridge.

6.3. Cable Relaxation Effects. In order to study the cable relaxation effects on the seismic response of cable-stayed bridges, a companion model of Model C, Model D, was conducted. Model D is similar to Model C except that cable relaxation was neglected by applying elastic material to cable models with elastic modulus the same as Model $\mathrm{C}$ at tension state. For Model D, cable elements were able to suspend compression force despite the fact that it was against the actual material properties of the cables. In this way, Model $\mathrm{D}$ should have the same seismic response as Model C until any of cable relaxations occurred. Figure 17 shows the peak response of Model D including deck and tower displacement, tension force of $\mathrm{C} 3$, and bending moment at tower bottom. In Figure 17, for comparing purpose, all the responses were normalized by that of Model C.

From Figure 17, the response of Model D, as expected, is exact to that of Model $\mathrm{C}$ before cable relaxation first occurred at PGA $=0.45 \mathrm{~g}$. After cable relaxation $(\mathrm{PGA} \geq$ $0.45 \mathrm{~g}$ ), one can see that Model D experienced slightly larger seismic response than Model $\mathrm{C}$ and it becomes more obvious as PGA increased. For tower displacement, tower bending moment, and deck displacement, the maximum difference between two models was less than $4 \%$ for all PGA levels while it was less than $12 \%$ for maximum cable force of $\mathrm{C} 4$. It is concluded that cable relaxation slightly enlarged the seismic response of cable-stayed bridges like tower displacement, bending moment at tower bottom, and deck displacement 
TABLE 8: Comparisons of normalized maximum and minimum cable forces between measured and numerical results.

\begin{tabular}{|c|c|c|c|c|c|c|c|}
\hline \multirow{2}{*}{ PGA } & \multicolumn{3}{|c|}{ Maximum tension force } & \multirow{2}{*}{ PGA } & \multicolumn{3}{|c|}{ Minimum tension force } \\
\hline & Test results & Numerical results & Difference & & Test results & Numerical results & Difference \\
\hline 0.05 & 1.092 & 1.098 & $0.5 \%$ & 0.05 & 0.886 & 0.903 & $1.7 \%$ \\
\hline 0.10 & 1.189 & 1.206 & $1.7 \%$ & 0.10 & 0.793 & 0.771 & $-2.2 \%$ \\
\hline 0.15 & 1.260 & 1.285 & $2.5 \%$ & 0.15 & 0.731 & 0.666 & $-6.5 \%$ \\
\hline 0.20 & 1.330 & 1.350 & $2.0 \%$ & 0.20 & 0.670 & 0.585 & $-8.5 \%$ \\
\hline 0.25 & 1.398 & 1.413 & $1.5 \%$ & 0.25 & 0.611 & 0.508 & $-10.3 \%$ \\
\hline 0.30 & 1.465 & 1.451 & $-1.4 \%$ & 0.30 & 0.559 & 0.454 & $-10.5 \%$ \\
\hline 0.35 & 1.523 & 1.505 & $-1.7 \%$ & 0.35 & 0.511 & 0.393 & $-11.8 \%$ \\
\hline 0.40 & 1.536 & 1.568 & $3.2 \%$ & 0.40 & 0.445 & 0.320 & $-12.5 \%$ \\
\hline 0.45 & 1.614 & 1.592 & $-2.2 \%$ & 0.45 & 0.383 & 0.253 & $-13.0 \%$ \\
\hline 0.50 & 1.681 & 1.582 & $-9.9 \%$ & 0.50 & 0.332 & 0.181 & $-15.1 \%$ \\
\hline 0.55 & 1.739 & 1.617 & $-12.1 \%$ & 0.55 & 0.299 & 0.118 & $-18.1 \%$ \\
\hline 0.60 & 1.769 & 1.695 & $-7.3 \%$ & 0.60 & 0.262 & 0.011 & $-25.1 \%$ \\
\hline 0.65 & 1.805 & 1.763 & $-4.2 \%$ & 0.65 & 0.205 & 0.000 & $-20.5 \%$ \\
\hline 0.70 & 1.873 & 1.868 & $-0.5 \%$ & 0.70 & 0.097 & 0.000 & $-9.7 \%$ \\
\hline 0.75 & 2.028 & 1.920 & $-10.8 \%$ & 0.75 & 0.082 & 0.000 & $-8.2 \%$ \\
\hline 0.80 & 2.048 & 1.947 & $-10.1 \%$ & 0.80 & 0.074 & 0.000 & $-7.4 \%$ \\
\hline
\end{tabular}

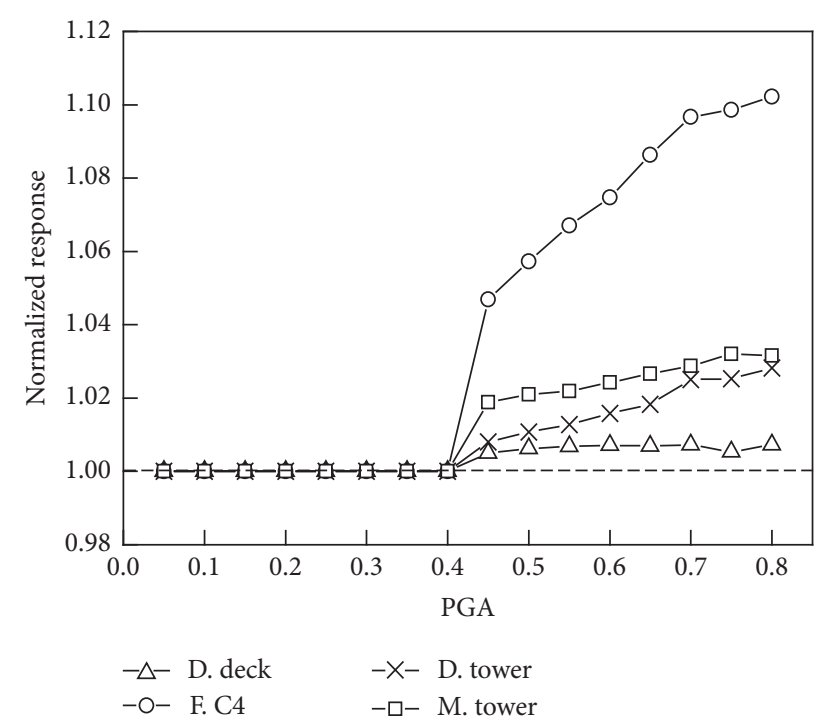

FIGURE 17: Normalized seismic response of Model D. Note: D. deck, deck displacement at deck end; D. tower, tower displacement at tower top; F. C4, maximum cable force of C4; M. tower, bending moment at tower bottom.

and maximum cable force, but its influence is quite small with maximum error less than $12 \%$.

\section{Conclusion}

The main objective of this paper was to describe experimental and analytical studies on seismic damage of cable-stayed bridges in longitudinal direction. From the set of results presented, the following conclusion can be drawn:
(1) The observed damage of the test model mainly concentrated at the tower including (1) several cracks at the bottom region of the tower leg when PGA $=0.3 \sim$ $0.5 \mathrm{~g}$, (2) parallel horizontal cracks from the bottom to nearly half height of the tower leg distributed at a nearly equal distance when PGA $=0.5 \sim 0.7 \mathrm{~g}$, and (3) concrete spalling and exposed longitudinal bars at top tower $0.2 \mathrm{~m}$ above the section where two skewed legs intersect.

(2) The stiffness of the bridge decreased as damage of the tower occurred and accumulated, leading to gradual elongation of natural period of the model.

(3) By modeling nonlinearity for different components of cable-stayed bridges, numerical model reflected test model of the measured acceleration and displacement response, cable tension force, and the observed damage with good agreement. It is thus concluded that nonlinear analytical techniques were able to simulate the elastic-plastic response of the cable-stayed bridge.

(4) Cable experienced large variation of tension force during the test, and cable relaxation was detected. Based on the numerical study, cable relaxation enlarged the seismic response of cable-stayed bridges like tower displacement, bending moment at tower bottom, deck displacement, and maximum cable force, but its influence is quite small with maximum error less than $12 \%$.

\section{Conflicts of Interest}

The authors declare that they have no conflicts of interest. 


\section{Acknowledgments}

This research is supported by the National Basic Research Program of China (no. 2013CB036302) and Strategic Study on the Technology Development of Marine Bridge Engineering. The support is gratefully acknowledged.

\section{References}

[1] MCPRC, Guidelines for Seismic Design of Highway Bridges, Ministry of Communications of the People's Republic of China, Beijing, China, 2008 (Chinese).

[2] D. M. Siringoringo, Y. Fujino, and K. Namikawa, "Seismic response analyses of the Yokohama Bay cable-stayed bridge in the 2011 great East Japan Earthquake," Journal of Bridge Engineering, vol. 19, no. 8, Article ID A4014006, 2011.

[3] A. Filiatrault, R. Tinawi, and B. Massicotte, "Damage to cablestayed bridge during 1988 saguenay earthquake. I: pseudostatic analysis," Journal of Structural Engineering (United States), vol. 119, no. 5, pp. 1432-1449, 1993.

[4] A. Filiatrault, R. Tinawi, and B. Massicotte, "Damage to cablestayed bridge during 1988 Saguenay earthquake. II: dynamic analysis," Journal of Structural Engineering, vol. 119, no. 5, pp. 1450-1463, 1993.

[5] K. C. Chang, Y. L. Mo, C. C. Chen, L. C. Lai, and C. C. Chou, "Lessons learned from the damaged Chi-Lu cable-stayed bridge," Journal of Bridge Engineering, vol. 9, no. 4, pp. 343-352, 2004.

[6] C. B. Chadwell and G. L. Fenves, "Near source earthquake effects on the Jilu cable-stayed bridge in the 21 September 1999 chi-chi taiwan earthquake," in Proceedings of the Community Workshop On Computational Simulation and Visualization Environment for NEES, W. M. Kim Roddis, Ed., National Science Foundation, University of Kansas, Lawrence, Kan, USA, 2003.

[7] J. Combault and J. P. Teyssandier, "The Rion-Antirion bridge: concept, design and construction," in Proceedings of the Structures Congress and the 2005 Forensic Engineering Symposium, pp. 1539-1550, New York, NY, USA, April 2005.

[8] S. Kite, K. Falbe-Hansen, T. Vejrum et al., "Stonecutters bridge-design for extreme events," in Proceedings of the IABSE Symposium Report, International Association for Bridge and Structural Engineering, vol. 90, no. 2, pp. 27-34, Lisbon, Portugal, 2005.

[9] Japan Road Association, Specifications for Highway Bridges, Maruzen, Tokyo, Japan, 2002.

[10] A. Camara and M. A. Astiz, "Pushover analysis for the seismic response prediction of cable-stayed bridges under multidirectional excitation," Engineering Structures, vol. 41, no. 3, pp. 444-455, 2012.

[11] H. Li, J. Liu, and J. Ou, "Investigation of seismic damage of cable-stayed bridges with different connection configuration," Journal of Earthquake and Tsunami, vol. 3, no. 3, pp. 227-247, 2009.

[12] M. J. Wesolowsky and J. C. Wilson, "Seismic isolation of cablestayed bridges for near-field ground motions," Earthquake Engineering and Structural Dynamics, vol. 32, no. 13, pp. 21072126, 2003.

[13] C. Ji, R. J. Archuleta, and C. Twardzik, "Rupture history of 2014 Mw 6.0 South Napa earthquake inferred from near-fault strong motion data and its impact to the practice of ground strong motion prediction," Geophysical Research Letters, vol. 42, no. 7, pp. 2149-2156, 2015.

[14] R. S. Jangid and J. M. Kelly, "Base isolation for near-fault motions," Earthquake Engineering and Structural Dynamics, vol. 30, no. 5, pp. 691-707, 2001.

[15] M. A. Garevski, J. M. W. Brownjohn, A. Blakeborough, and R. T. Severn, "Resonance-search tests on a small-scale model of a cable-stayed bridge," Engineering Structures, vol. 13, no. 1, pp. 59-66, 1991.

[16] J. Li, J. Yan, T. Peng, and L. Han, "Shake table studies of seismic structural systems of a Taizhou Changjiang Highway Bridge model," Journal of Bridge Engineering, vol. 20, no. 3, 2015.

[17] X. Duan, Experimental Study on Seismic Performance of CableStayed Bridge Tower Subjected to Longitudinal Strong Ground Motions, Tongji University, Shanghai, China, 2012 (Chinese).

[18] R. Wang, Y. Xu, and J. Li, “Transverse seismic behavior studies of a medium span cable-stayed bridge model with two concrete towers," Journal of Earthquake Engineering, vol. 21, no. 1, pp. 151168, 2017.

[19] P. D. Moncarz and H. Krawinkler, Theory and Application of Experimental Model Analysis in Earthquake Engineering, Stanford University, 1981.

[20] G. P. Mavroeidis and A. S. Papageorgiou, "A mathematical representation of near-fault ground motions," Bulletin of the Seismological Society of America, vol. 93, no. 3, pp. 1099-1131, 2003.

[21] S. Mazzoni, F. McKenna, M. H. Scott et al., OpenSees Command Language Manual, Pacific Earthquake Engineering Research (PEER) Center, 2006.

[22] H. J. Ernst, "Der E-modul von seilen unter berucksichtigung des durchhanges," Der Bauingenieur, Berlin, vol. 40, no. 2, pp. 52-55, 1965 (German).

[23] A. S. Nazmy and A. M. Abdel-Ghaffar, "Non-linear earthquakeresponse analysis of long-span cable-stayed bridges: theory," Earthquake Engineering \& Structural Dynamics, vol. 19, no. 1, pp. 45-62, 1990.

[24] W.-X. Ren and M. Obata, "Elastic-plastic seismic behavior of long span cable-stayed bridges," Journal of Bridge Engineering, vol. 4, no. 3, pp. 194-203, 1999.

[25] D. C. Kent and R. Park, "Flexural members with confined concrete," Journal of the Structural Division, vol. 97, pp. 19691990, 1971.

[26] B. A. Zárate and J. M. Caicedo, "Effects of cable dynamics in the modeling of cable-stayed bridges under seismic excitation," International Journal of Structural Stability and Dynamics, vol. 15, no. 4, Article ID 1450061, 2015. 


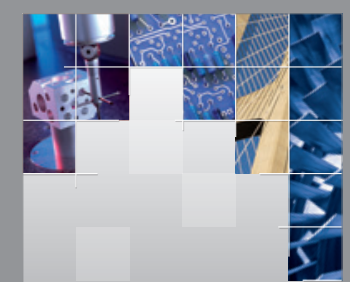

\section{Enfincering}
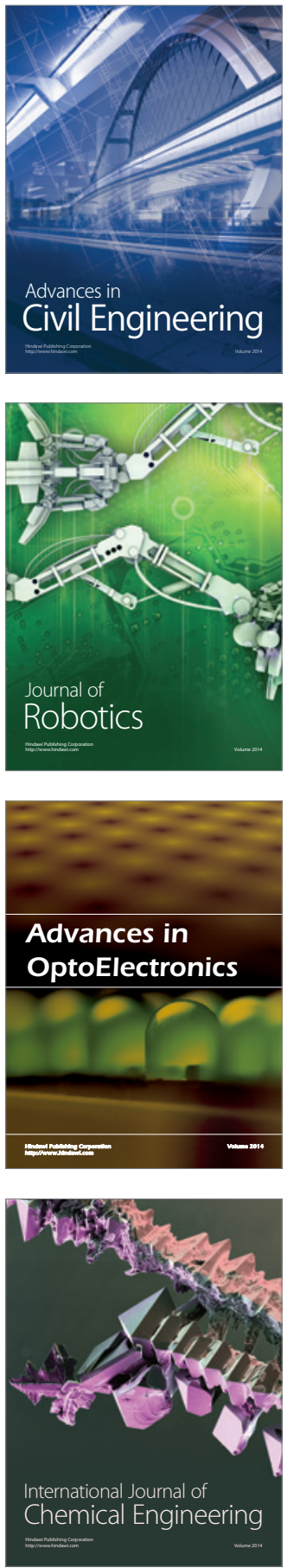

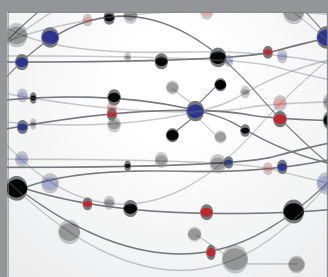

The Scientific World Journal

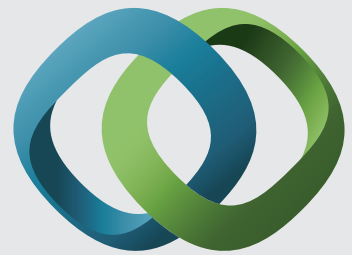

\section{Hindawi}

Submit your manuscripts at

https://www.hindawi.com
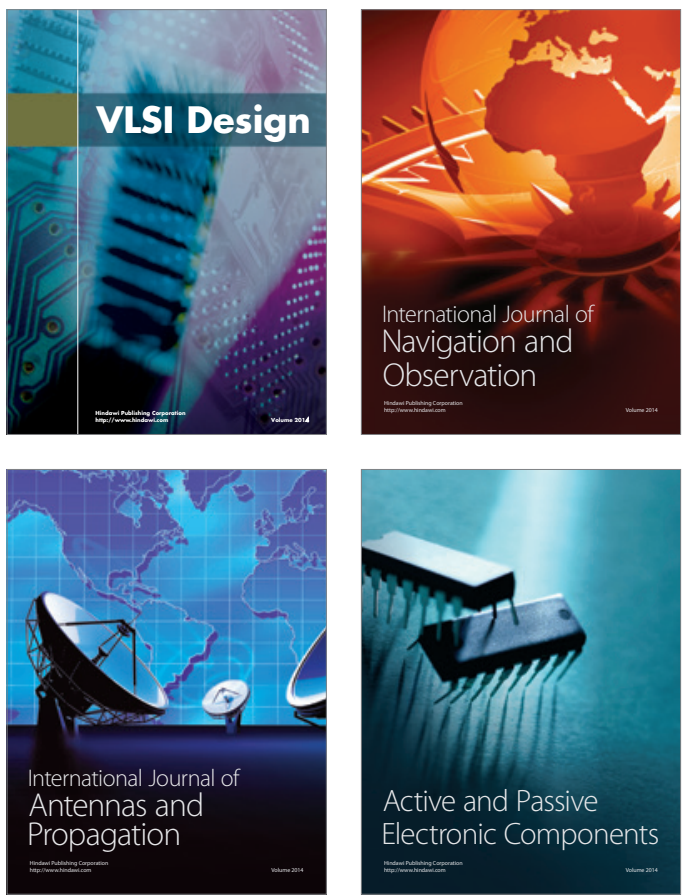
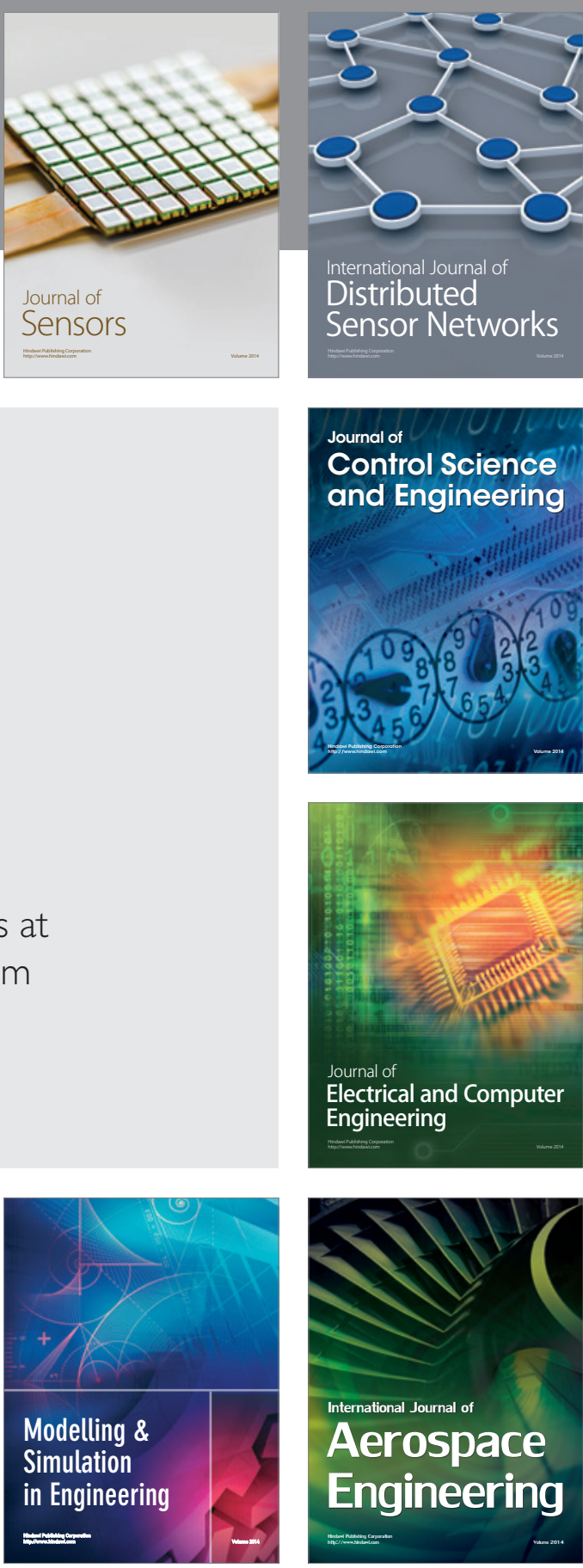

International Journal of

Distributed

Sensor Networks

$-$

Joumal of

Control Science

and Engineering
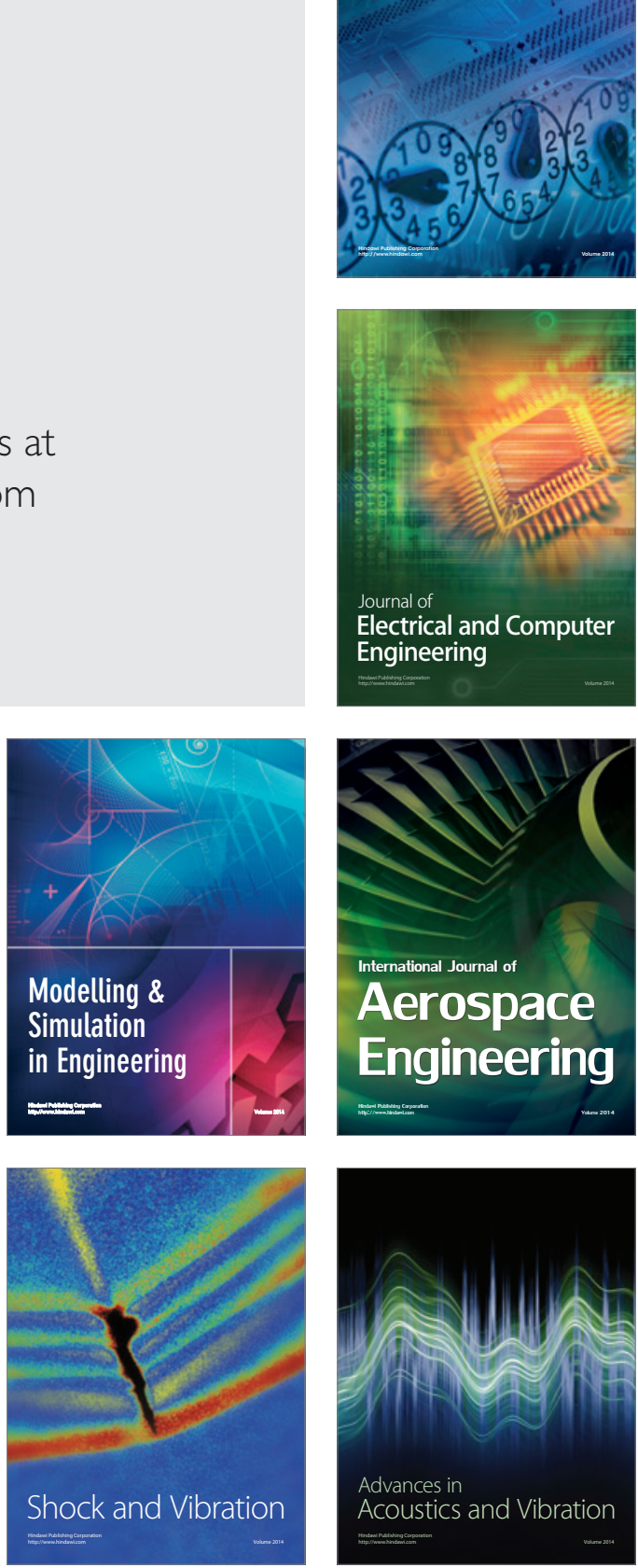